\title{
SWOT analiza inovacionog sistema u Bosni i Hercegovini
}

\author{
Miloš Trifković ${ }^{*}$ \\ Dženana Husremović ${ }^{* *}$
}

\begin{abstract}
Sažetak: Aktualna globalna pozicija Bosne i Hercegovine potvrđuje nalaz prethodnih istraživanja da u našoj državi ne postoji jedinstven ili barem harmonizovan i efikasan inovacioni sistem, primjeren potrebama razvoja društva i ekonomije znanja. Prvi koraci u utvrđivanju razloga ovakvog stanja su SWOT analize položaja i uloge inovacionog sistema u okviru opšteg strateškog planiranja i sektorskog planiranja istraživanja i transfera tehnologije. Najvažniji rezultati dobiveni iz tih matrica su diskutovani u radu. Oni su potom uspoređeni sa rezultatima naših najnovijih istraživanja. Prvi rezultat je sažeta SWOT matrica inovacionog sistema. Rezultate razrade pojedinih faktora smo prikazali u detaljnoj SWOT matrici zasnovanoj na elementima snage. I ova matrica je pokazala da je ujednačeno i stabilizirano visoko obrazovanje najvažniji element snage inovacionog sistema. Zbog toga su obilježja univerziteta kao subjekta inovacionog sistema posebno razmotrena.
\end{abstract}

Ključne riječi: Bosna i Hercegovina, društvo i ekonomija znanja, inovacioni sistem, SWOT analiza inovacionog sistema, opšte strategije razvoja, sektorske strategije razvoja inovacionog sistema, univerziteti kao subjekti inovacionog sistema.

\section{Uvodne napomene}

Inovacioni sistem i globalna ekonomska pozicija Bosne i Hercegovine

Inovacioni sistem je složen socijalni podsistem nastao interakcijom subjekata u procesima stvaranja, primjene, distribucije i diseminacije naučno zasnovanih znanja radi dostizanja ciljeva koje društvo postavlja. ${ }^{1}$ Uporedno posmatrano, osnovni elementi inovacionih sistema na nacionalnom ili supranacionalnom nivou su isti: resursi, subjekti i regulatorni sistemi. Izgled elemenata, njihove uzajamne veze, način funkcionisanja cijelog inovacionog sistema i njegovi odnosi s drugim podsistemima zavise od historijskih i aktuelnih, spoljnih i unutrašnjih okolnosti svakoga društva. Isti faktori određuju sistem ciljeva. U savremenim uslovima, najouopšteniji teorijski cilj inovacionog sistema je

\footnotetext{
* Redovni član Akademije nauka i umjetnosti Bosne i Hercegovine. E-mail: iucomt@yahoo.com ${ }^{* *}$ Redovna profesorica Filozofskog fakulteta Univerziteta u Sarajevu, prorektorica za nastavu Univerziteta u Sarajevu. E-mail: dzenana.husremovic@ff.unsa.ba

${ }^{1}$ Trifković, 2020a: 41, vidjeti i Trifković, 2020b: 40-41.
} 
stvaranje i dalji razvoj društva i ekonomije znanja kao instrumenta podizanja individualne i opšte dobrobiti, prvenstveno unutar zajednice. Hijerarhijski niži ciljevi se određuju prema pragmatičnom zahtjevu podizanja konkurentnosti nacionalne privrede. Zbog toga zadaci, struktura, način djelovanja i rezultati konkretnog inovacionog sistema u krajnjoj liniji zavise od ustrojstva države i stepena ukupne razvijenosti društva. ${ }^{2}$ Ta zakonitost se ispoljava i u slučaju Bosne i Hercegovine.

Za potrebe ovog rada, ustrojstvo države će se sažeti na njen pravni sistem. Opis i kritička analiza ustavne i zakonske regulative i njenog nezadovoljavajućeg uticaja na stanje inovacionog sistema Bosne i Hercegovine već postoje. ${ }^{3}$ Loše normativno i stvarno uređenje inovacionog sistema je istovremeno i posljedica i uzrok nezadovoljavajuće razvijenosti bosanskohercegovačkog društva, države i privrede i slabog položaja Bosne i Hercegovine u globalnoj utakmici. Za ovakav stav postoji obilje argumenata. U globalnim sintetičkim indeksima razvijenosti i konkurentnosti država u posljednjih deset godina, osim u ljudskom kapitalu, Bosna i Hercegovina po pravilu zauzima mjesto $u$ donjoj polovini zemalja obuhvaćenih rangiranjem. ${ }^{4}$ Podaci Svjetske banke o indikatorima razvoja nauke i tehnologije u periodu 2010 - 2018. g. nisu ništa povoljniji za nas. ${ }^{5}$ Njihovo ispitivanje pokazuje da Bosna i Hercegovina zaostaje ne samo za svijetom, Evropom i Centralnom Azijom, nego i za državama koje su u procesu disolucije Jugoslavije nastale osamostaljivanjem njenih najnerazvijenijih republika. ${ }^{6}$ Zbog toga ne začuđuje što je Svjetski ekonomski forum u svome Izvještaju o konkurentnosti za period 2017-2018.

\footnotetext{
${ }^{2}$ Izvanrednu ilustraciju ove teze, poučnu i za BiH, vidjeti kod Raadošević \& Lepori, 2009: 659-666.

${ }^{3} \mathrm{O}$ ustavnom sistemu BiH vidjeti Trifković. 2020b: 83 - 95 i Trifković, 2020a: 44 - 48. Za uporedni pregled najvažnijih zakonskih rješenja sva tri nivoa vlasti u BiH vidjeti Trifković, 2020b: 109 - 120 i Trifković, 2020b: 173 - 186.

${ }^{4}$ Jedan od najopštijih pokazatelja razvijenosti je BDP po glavi stanovnika izračunat prema kupovnoj snazi valute (PPP). Prema rangiranju Svjetske banke, Bosna i Hercegovina je u 2019. g zauzimala 96. mjesto od 189 zemlja. Iste godine UN je svrstao $\mathrm{BiH}$ na 95. poziciju od 193 države. Prema Wikipedia, 2021. g. BiH se nalazi na 92. mjestu od 141 države To je bolji plasman nego u 2016. g (107) i 2017 -18. g.( 103). Navedeni podaci su indikativni čak i kad se uzmu u obzir relevantni prigovori metodologiji WEF, te promjene cilja rangiranja i izboru indikatora za 2019. godinu, prema Schwab, 2019.. Global Innovation Indeks (GII) Kornell Univerziteta i WIPO u 2020. g. svrstava BiH na 74. mjesto među 131 državom, što je poboljšanje za dva mjesta u odnosu na 2019. g. i za četiri mjesta prema rangu za 2018. g. Ipak, i s navedenim poboljšanjima plasmana, BiH među 39 ekonomija u Evropi, zauzima 38. tj. pretposljednje mjesto prema World Intelectual Property Organization, 2020.

${ }^{5}$ Vidjeti podatke u World Bank (2021).

${ }^{6}$ Trifković, 2020a: 55.
} 
svrstao Bosnu i Hercegovinu grupu zemalja koje svoj razvitak zasnivaju na efikasnosti u iskorištavanju resursa, a ne na inovacijama. ${ }^{7}$ Očito, proces intenzivnog stvaranja društva i ekonomije znanja kod nas je tek u začetku. ${ }^{8}$

Razlozi nezadovoljavajućeg stanja inovacionog sistema i loših rezultata ekonomske, ali i socijalne ${ }^{9}$ konkurentnosti Bosne i Hercegovine najvećim dijelom imaju unutrašnju provenijenciju i sistemski karakter. Oni se mogu sažeto izraziti kao razvojnim potrebama neprilagođen tretman inovacionog sistema $u$ zemlji. Drugim riječima, inovacioni sistem Bosne i Hercegovine, unutar društva i države kojima služi, funkcioniše u nepovoljnom socijalnom, političkom, ekonomskom i pravnom okruženju. Ovakva situacija zahtijeva analizu stanja i mogućnosti inovacionog sistema da prevaziđe postojeću situaciju.

\section{Metodološke odrednice}

Aktualna globalna pozicija Bosne i Hercegovine potvrđuje nalaz prethodnih istraživanja da ,u našoj državi ne postoji jedinstven ili harmonizovan i efikasan inovacioni sistem primjeren društvenim potrebama. " ${ }^{\text {"10 }}$ Stoga, glavni problem rada je: utvrditi najvažnije snage i slabosti koje, povezane sa prilikama i prijetnjama, oblikuju inovacioni sistem u Bosni i Hercegovini i determinišu njegov potencijal za razvoj cjelokupnog društva. U postojećoj situaciji, glavni cilj istraživanja mora da bude ukazivanje na elemente inovacionog sistema koji suštinski određuju njegovu stagnaciju ili razvojnu dinamiku, a time i kretanje Bosne i Hercegovine ka društvu i ekonomiji znanja. Primarna hipoteza glasi: sadašnji položaj inovacionog sistema ubjedljivo determiniraju slabosti koje ograničavaju ne samo njegov, nego i razvoj Bosne i Hercegovine. U skladu s navedenom glavnom pretpostavkom dominantan predmet istraživanja će biti inovacioni sistem.

Izložene metodološke odrednice nameću interdisciplinarni pristup istraživanju. U njemu dominiraju postupci karakteristični za ekonomske, pravne i

\footnotetext{
${ }^{7}$ Schwab, 2017:320.

${ }^{8} \mathrm{O}$ uslovima i problemima razvoja koji bivše socijalističke države vodi u grupu zemalja čiju privredu pokreću efikasnost i inovacije, vidjeti Radošević, 2011.

${ }^{9}$ Bez obzira na svega 3,5 miliona stanovnika, Bosna i Hercegovina se 21. 5. 2021. g. nalazila na 45. mjestu svjetske liste po apsolutnom broju umrlih od COVID-19 prema Statista, 2021). Pored toga, dostupan je i podatak u kojem se izvještava da je u Bosni i Hercegovini prvom dozom vakcinisano svega 76.311 građana. Podaci o broju vakcinisanih u R. Hrvatskoj i R. Srbiji su još uvijek nepoznati, prema Babić, 2021.

${ }^{10}$ Trifković, 2020b: . 69. Ovaj zaključak je, na žalost, potvrđen istraživanjem stvarnog stanja inovacionog sistema na teritoriji FBiH. U tom smislu vidjeti Kremić \& Trifković, 2020.
} 
političke nauke. Tema i glavni problem rada zahtijevaju kraći osvrt jedino na specifičnosti primjene SWOT analize.

\section{Napomene o načinu korištenja SWOT analize}

SWOT analiza je metoda strateškog menadžmenta kojom se utvrđuju i međusobno ispituju sadašnje i buduće ${ }^{11}$ unutrašnje snage i slabosti subjekta ili društvenog (pod)sistema, te prilike i prijetnje iz okruženja. Nastala je sedamdesetih godina prošlog vijeka. ${ }^{12}$ Najprije se koristila za utvrđivanje tržišnog položaja preduzeća, a potom se proširila i na druge oblasti. ${ }^{13}$ Povećan domen primjene SWOT analize i njenog derivata TOWS matrice, rezultirao je sve učestalijim povezivanjem ovih instrumenata $s$ drugim metodološkim postupcima strategijske analize okruženja. ${ }^{14}$ Nakon 2017. godine u Bosni i Hercegovini dominira povezivanje SWOT matrice sa PESTEL metodom.

U primjeni na inovacioni sistem uopšte, a konkretno u Bosni i Hercegovini, SWOT analiza ispoljava neke osobine uslovljene predmetom istraživanja. Ona, najprije, ima makro karakter koji zahtijeva da se svaki od četiri SWOT faktora odredi uzimajući u obzir veliki broj elemenata domaće i međunarodne provenijencije. Granicu između unutrašnjih i spoljnih faktora, između nacionalnog i globalnog, te između postojećih i elemenata u nastajanju nije uvijek moguće jasno povući. Pogreške u svakom od tri domena su opasne naročito pri operacionalizaciji međunarodne komponente strategije i izradi strateških scenarija razvoja inovacionog sistema, Drugo, pojedini faktori se sastoje od velikog broja po pravilu složenih elemenata, što nameće potrebu njihovog sažimanja. Taj postupak najprije svakom elementu, a onda i faktoru SWOT analize nužno daje sintetski karakter. Povećana mjera sažimanja stvara opasnost osiromašenja sadržaja pojedinih elemenata i faktora. U narednom koraku, redukcionistički pristup otežava utvrđivanje uticaja inovacionog sistema na ubrzavanje, stagnaciju ili usporavanje ukupnog razvoja Bosne i Hercegovine. ${ }^{15}$ Treće, gotovo nijedan od elemenata bilo kojeg faktora SWOT analize inovacionog sistema se u praksi ne pojavljuje u čistom obliku i sa

\footnotetext{
${ }^{11}$ Fleisher \& Bensoussan, 2007: 54-77 i . Fleisher \& Bensoussan, 2007: 87-103

${ }^{12}$ Ibidem

${ }^{13}$ Božac, 2008: 20-23

${ }^{14}$ Božac, 2008: 24 -27. i Fleisher \& Bensoussan, 2015

${ }^{15} \mathrm{Na}$ ovu opasnost upozorenje vidjeti u Nikolić, s.a. gdje se navodi da SWOT analiza „ima tendenciju da previše uprošćava situaciju klasifikujući faktore okruženja u kategorije u koje ne moraju uvek da spadaju u potpunosti““
} 
jednoznačnim efektima. Zbog toga je određivanje sadržaja konkretnih elemenata, njihova klasifikacija po faktorima SWOT analize i mjeri uticaja na inovacioni sistem uvijek značajnim dijelom i rezultat individualne ili grupne procjene. Stoga se nameće zaključak da ni u istraživanju inovacionog sistema nije moguće izbjeći prigovor subjektivizma, koji generalno relativizira vrijednost rezultata SWOT analize. ${ }^{16}$ Ipak, prednosti SWOT analize su takve da se ona bez obzira na metodološke probleme redovno koristi pri izradi strategija razvoja u Bosni i Hercegovini.

\section{SWOT analiza inovacionog sistema u strategijama razvoja u Bosni i Hercegovini}

\section{Odnos strateškog planiranja razvoja u Bosni i Hercegovini prema SWOT analizi}

Osnovne protivrječnosti sistema strateškog planiranja razvoja u Bosni i Hercegovini, uključujući i razvoj inovacionog sistema, imaju ustavni karakter. ${ }^{17}$ Prva je suprotnost između jedinstvenosti teritorijalnog, ${ }^{18}$ ekonomskog i socijalnog ${ }^{19}$ prostora Bosne i Hercegovine i izuzetno velikih nadležnosti nižih u odnosu na više nivoe političko teritorijalnog organizovanja. Njen krajnji izraz je ustavna pretpostavka da niži nivoi državne organizacije imaju sve nadležnosti koje nisu izričito date višoj političko-teritorijalnoj jedinici. ${ }^{20}$ Druga suprotnost je ograničavanje isključivih nadležnosti države Bosne i Hercegovine i njenih institucija na relativno mali broj ekonomskih funkcija dominanto međunarodnog karaktera ${ }^{21}$ bez postojana unutrašnjih mehanizama za samostalno ostvarenje preuzetih obaveza i prava sa elementom inostranosti. Za ilustraciju konačnih posljedica ove protivrječnosti navodimo Odluku Vijeća ministara o sistemu koordinacije procesa europskih integracija u Bosni

\footnotetext{
${ }^{16}$ Vidjeti Fleisher \& Bensoussan, 2007: 94

${ }^{17}$ Pregled ustavnih rješenja u Bosni i Hercegovini, relevantnih za inovacioni sistem, vidjeti u Trifković, 2020b: 83-91.

${ }^{18}$ Vidjeti C̆l. I, 1. Ustava Bosne i Hercegovine."

${ }^{19}$ Vidjeti st. 4 Preambule i Čl. I. 4. Ustava Bosne i Hercegovine.

${ }^{20} \breve{C}$ l. 3, 1.a) Ustava Bosne i Hercegovine: „Sve vladine funkcije i ovlaštenja koja nisu ovim ustavom izričito dana institucijama Bosne i Hercegovine, pripadaju entitetima.“ Evolucija ustavnog prava je modifikovala „ustavnu stvarnost“" u ovom i u drugim domenima (Vidjeti: Steiner, 2010: 529. i dalje), ali nije promijenila osnovni model organizacije države.

${ }^{21}$ Čl. III.1 Ustava Bosne i Hercegovine. Prema Čl. III. 5 Država može steći dodatne nadležnosti dogovorom entiteta. Treba zapaziti da nadležnosti dodijeljene ovim članom u suštini imaju spoljno-politički karakter.
} 
i Hercegovini. ${ }^{22}$ Taj akt, propisivanjem metoda horizontalne i vertikalne koordinacije, uključuje u odlučivanje o pitanjima pridruživanja Evropskoj uniji sve niže nivoe vlasti $\mathrm{BiH}$ i time im de facto daje pravo na vršenje državnih nadležnosti u međunarodnim odnosima. ${ }^{23}$ Navedene protivrječnosti posredno utiču i na SWOT analize za potrebe strateškog planiranja kod nas.

Pravno uređenje jednoobraznog sistema strateškog planiranja u Bosni i Hercegovini je pred završetkom. Shodno ustavnim nadležnostima, na nivou Države ono se odvija kao planiranje institucija Bosne i Hercegovine. ${ }^{24}$ Njegovu osnovu čini strateški okvir koji uključuje dokumente Predsjedništva $\mathrm{BiH}$, Parlamentarne skupštine i Vijeće ministara. Na bazi utvrđenog okvira se posebnom metodologijom ${ }^{25}$ rade trogodišnji, tj. srednjeročni i dugoročni programi rada Vijeća ministara. ${ }^{26} \mathrm{Za}$ analizu okruženja Uputstvo o metodologiji posebno preporučuje SWOT i PESTLE pristup. Posljednji javno dostupan „Strateški okvir za BiH“ za period 2016.- 2018. g. je analizu društveno-ekonomskog stanja zasnovao na SWOT matrici. ${ }^{27}$ Zbog toga iznenađuje da šesti po redu nacrt „Srednjoročnog program rada 2021-2023“ Vijeća ministara iz maja 2020. godine. ${ }^{28}$ ne koristi ovu metodologiju. ${ }^{29}$

Zakon o razvojnom planiranju i upravljanju razvojem u Federaciji Bosne i Hercegovine iz 2017. godine ${ }^{30}$ (ZRP FBiH) je stvorio jedinstven i sa ustavnim nadležnostima entiteta i kantona usuglašen sistem planiranja razvoja. Njegova primjena je operacionalizirana sa deset uredbi i jednom metodologijom za izračun indeksa razvoja jedinica lokalne samouprave. ${ }^{31}$ Nama je najinteresantnija Uredba o izradi strateških dokumenata u Federaciji Bosne i Hercegovine. ${ }^{32}$ Prema njenom članu 17. prvi korak u izradi strateške platforme

\footnotetext{
${ }^{22}$ Bosna i Hercegovina. Vijeće Ministara. (2016).

${ }^{23}$ Tačnost navedenog zaključka potvrđuje naročito član 3 Odluke: „Način odlučivanja“

${ }^{24}$ Bosna i Hercegovina. Vijeće Ministara. (2014).

${ }^{25}$ Bosna i Hercegovina. Vijeće Ministara. (2014).

${ }^{26}$ Vidjeti naročito „Dio drugi - srednjoročno planiranje“ Bosna i Hercegovina. Vijeće Ministara, 2014.

${ }^{27}$ Bosna i Hercegovina. Vijeće Ministara Bosne i Hercegovine. Direkcija za ekonomsko planiranje, 2015:30 - 33.

${ }^{28}$ Bosna i Hercegovina. Vijeće Ministara Bosne i Hercegovine, 2020.

${ }^{29}$ Bosna i Hercegovina. Vijeće Ministara Bosne i Hercegovine, (2010) je uključivao dokument: „SWOT analiza razvoja ekonomije - integrisana“, pa ćemo se kasnije osvrnuti na njega.

${ }^{30}$ Službene novine Federacije Bosne i Hercegovine br. 32/17

${ }^{31}$ Vidjeti Federacija Bosne i Hercegovine. Federalni zavod za programiranje razvoja. Uredbe (https://www.fzzpr/gov.ba/bos/docs/35/8/uredbe).

${ }^{32}$ Službene novine Federacije Bosne i Hercegovine br. 74/19
} 
je situaciona analiza unutrašnjeg i vanjskog okruženja „u cilju utvrđivanja stvarnih faktora i potencijala za razvoj područja, odnosno sektora, te ograničenja i prepreka." Time je SWOT analiza, barem na području Federacije Bosne i Hercegovine $(\mathrm{FBiH})$, postala pravno obavezna metodologija. Praksa je potvrdila ovaj zaključak. Generalni strateški dokumenti u Federaciji, završeni nakon donošenja ZRP FBiH, redovno sadrže SWOT analizu koja uključuje i elemente inovacionog sistema. ${ }^{33}$

Osnov strategijskog planiranja razvoja u Republici Srpskoj (RS) je Član 68. st. 1, tačka 8. njenog Ustava, koji obavezuje ovaj entitet da, između ostalog, uređuje i obezbjeđuje ,osnovne ciljeve i pravce privrednog, naučnog, tehnološkog ... razvoja“. Na toj osnovi je u skladu sa propisima o funkcionisanju Vlade i upravnih organa donesen niz sektorskih strategija. Sâmo Ministarstvo za tehnološki razvoj, visoko obrazovanje i informaciono društvo na svojoj stranici navodi dvije usvojene strategije i tri akciona plana. ${ }^{34}$ Sredinom aprila 2021. godine je na stranici Narodne skupštine RS objavljen je nacrt „Zakona o strateškom planiranju i upravljanju razvojem u Republici Srpskoj“..35 Predložena rješenja upućuje na suštinsku sličnost sa sistemom strateškog planiranja koji postoji u entitetu FBiH.

Donošenjem Zakona o strateškom planiranju i upravljanju razvojem u Republici Srpskoj stručni principi strateškog planiranja će u cijeloj zemlji dobiti i pravni karakter. Među najvažnijim načelima su: partnerstvo svih nivoa državne vlasti sa jedinicama lokalne samouprave, vertikalna i horizontalna koordinacija, sinhronizacija planiranja, komplementarnost strategija, te efikasnost i efektivnost planiranja. Potreba poštivanja navedenih načela uticaće i na način izrade SWOT analize. Ona će, najprije, postati obavezna i koristiti se povezano sa ostalim metodologijama strateškog planiranja. Drugo, pri konkretizaciji elemenata svakog faktora tvorci analize će morati poštovati ustavnu nadležnost nivoa vlasti za koji se strategija radi. I treće, uvažavanje principa strateškog planiranja će sigurno uticati na odabir elemenata koji čine svaki faktor SWOT analize, sadržaj koji se daje odabranim elementima i preciznost formulacija kojima se elementi definišu.

\footnotetext{
${ }^{33}$ Federacija Bosne i Hercegovine. Vlada Federacije Bosne i Hercegovine (2021). Prema čl. 16. st. 5. Zakona o razvojnom planiranju konačnu odluku donosi Parlament FBiH. Pregled stanja poslova na izradi kantonalnih strategija, pretežno za period 2021-2027. g. se nalazi na web tranici Federalnog zavoda za programiranje razvoja (https:/www.fzzpr.gov.ba/bs/ docs/25/4/kantonalni-strateški -dokumenti)

${ }^{34}$ Republika Srpska. Vlada Republike Srpske (2017).

${ }^{35}$ Republika Srpska. Narodna skupština Republike Srpske. Materijali za 16. Redovnu sjednicu
} 
Elementi SWOT analize inovacionog sistema u strateškim razvojnim dokumentima u Bosni i Hercegovini

Zastupljenost elemenata inovacionog sistema u SWOT analizama opštih strateških razvojnih dokumenata je važan indikator odnosa nosilaca planiranja i političkog odlučivanja u Bosni i Hercegovini prema društvu i ekonomiji znanja. Da bismo utvrdili tretman inovacionog sistema u strateškim planovima, ispitali smo SWOT analize u ukupno 13 pripremnih materijala, prijedloga i generalnih strategija razvoja, bez obzira na njihovo pravno važenje. Time je istraživanjem obuhvaćena cijela teritorija Bosne i Hercegovine u, za naše uslove, relativno dugačkom periodu od 2010. do 2027. godine. Elemente faktora SWOT analize inovacionog sistema koje neki, pretežno noviji, dokumenti navode prema PESTEL metodi, preuzeli smo nezavisno od oblasti u kojoj se nalaze i od učestalosti pojavljivanja. Značenje pojedinog elementa je utvrđivano najprije samo za sebe, a potom i u vezi sa drugim elementima istog i drugih faktora SWOT analize. Pri tome smo imali na umu da zbog različitih nadležnosti pojedinih subjekata strateškog planiranja, analize sadržaja u ovom slučaju može biti korisna samo u ograničenoj mjeri. Tabela br. 1: „Elementi inovacionog sistema u SWOT analizama razvojnih dokumenata“", koja se nalazi u prilogu nudi ukupne rezutate. U suštini, Tabela br. 1. je SWOT matrica inovacionog sistema Bosne i Hercegovine, ekstrapolirana iz postojećih dokumenta opšteg strateškog planiranja u državi. Bez obzira na sva metodološka ograničenja, tabelarni pregled omogućava nekoliko osnovnih zaključaka o položaju inovacionog sistema u Bosni i Hercegovini. Navodimo najvažnije.

Najprije, faktori ekstrapolirane SWOT matrice inovacionog sistema imaju sljedeći broj elemenata: snage -10 , slabosti -16 , prilike -7 i prijetnje -8 . Time se potvrđuje dominacija faktora slabosti, karakteristična za opšte strateške dokumente i za sektorske strategije razvoja inovacionog sistema. Među elementima snage dominiraju oni koji se tiču sistema i kvaliteta visokog obrazovanja. Interesantno je da o ovom elementu postoji saglasnost sva tri nivoa vlasti. ${ }^{36}$ Time se Bosna i Hercegovina svrstava u zemlje kojima apsolutno dominira državno finansiranje nauke skoro isključivo preko univerziteta. ${ }^{37}$

\footnotetext{
${ }^{36}$ Vidjeti Tabelu br. 1, redne brojeve 1.1. -1.4.

${ }^{37}$ Radošević, (2011): Tabela 3, tabelarno prikazuje četiri osnovna institucionalna profila (uključujući i Kazahstan) odnosa finansiranja i izvođenja istraživanja u bivšim socijalističkim zemljama. Bosna i Hercegovina se ne nalazi u tabeli. Na osnovu poznatih podataka može se smatrati da Bosna i Hercegovina spada u treći profil: država je najveći finansijer, a univerziteti najveći izvršioci istraživanja.
} 
Među slabostima na prvom mjestu su one sistemskog karaktera. Od njih devet treba navesti četiri: nedovoljan pravni i strateški okvir, nepoticajnu poresku i carinsku politiku, slabu povezanost javnog, privrednog i univerzitetskog sektora (Triple Helix) ${ }^{38}$, te nedovoljnu zaštitu autorskih prava itd. ${ }^{39}$ Drugo mjesto zauzimaju četiri slabosti vezane za tehnologiju. ${ }^{40}$ Napokon, starenje stanovništva i odlazak mladih obrazovanih kadrova u inostranstvo je treća slabost. Izgleda da ovaj proces više pogađa kantone, ${ }^{41}$ nego FBiH i Državu Bosnu i Hercegovinu. Od sedam prilika njih četiri imaju eksternu provenijenciju: strana ulaganja povezna sa novim tehnologijama, ubrzavanje 4.0 industrijske revolucije, mogućnosti uključivanja u nove lance vrijednosti uz pametnu specijalizaciju i korištenje fondova EU za istraživanje i razvoj. ${ }^{42}$ Od prilika pod dominantnom kontrolom domaćih subjekata nalaze se: razvoj STEM obrazovanja, ubrzavanje Triple Helix procesa i osnivanje naučno-tehnoloških parkova. ${ }^{43}$ Među prijetnjama se na prvom mjestu nalazi kadrovski odliv u inostranstvo, posebno deficitarnih struka. Iako ova prijetnja nije raščlanjena na više elemenata, ona predstavlja opšte mjesto u strateškim dokumentima kantona. ${ }^{44} \mathrm{U}$ oblasti tehnologije najveće opasnosti predstavljaju domaća ili strana ulaganja u zastarjele tehnologije, ${ }^{45}$ što je samo po sebi znak nerazvijenosti privrednog sistema. Zajednički nazivnik za sve slabosti iz ove matrice je marginalizacija bosanskohercegovačke ekonomije i društva. Najveća skupina prijetnji nalazi se u domenu transfera znanja iz nauke u privredu. U njoj su identifikovana četiri elementa: slaba institucionalna podrška, nedovoljni kapaciteti specijaliziranih institucija, nedostatak specijaliziranih kapaciteta i nedovoljan nivo direktne saradnje nauka - privreda. ${ }^{46}$

Druga grupa zaključaka odnosi se na kontradiktornosti unutar izvedene SWOT matrice inovacionog sistema. Navodimo najvažnije slučajeve. Prvi je slučaj protivrječnost između određivanja stabilne dostupnosti naučnika i kvalifikovanih kadrova kao elementa snage, uz istovremeno navođenje slabosti

\footnotetext{
${ }^{38}$ Budući da je na upitnik odgovorilo svega pet preduzeća, isključivo kao ilustraciju navodimo da je u periodu 2016 - 2018. g. u FBiH samo jedno od njih dobilo iz javnih fondova podršku za naučnoistraživačke aktivnosti (Kremić \& Trifković, 2020:36)

${ }^{39}$ Vidjeti Tabelu br. 1, redne brojeve: 2.6, 2.9, 2.11 - 2.14 i 2.16.

${ }^{40}$ Vidjeti Tabelu br. 1, redne brojeve istraživanja 2.1. - 2.4 i 2.14

${ }^{41}$ Vidjeti Tabelu br. 1, redni broj 2.10

${ }^{42}$ Vidjeti Tabelu br. 1, redne brojeve :3.1., 3.2., 3.5. i 3.7.

${ }^{43}$ Vidjeti Tabelu br. 1, redne brojeve: 3.4., 3.3. i 3.6.

${ }^{44}$ Vidjeti Tabelu br. 1, redni broj 4.1.

${ }^{45}$ Vidjeti Tabelu br. 1, redne brojeve 4.2. i 4.3.

${ }^{46}$ Vidjeti Tabelu br. 1, redne brojeve 4.4 i 4.6. -4.8 .
} 
koja se ogleda u tome da tehnološki usmjerena preduzeća napuštaju $\mathrm{BiH}$ zbog nedostatka visokokvalifikovane istraživačke i radne snage. Na istu kontradikciju upućuje i određivanje odliva najkvalifikovanijih kadrova kao opasnosti po privredni razvoj države. ${ }^{47}$ Drugi slučaj je međusobno isključivanje navodno dobre saradnje između univerziteta i industrije u oblasti istraživanja i razvoja, kao elementa snage i niskog nivoa dodatne vrijednosti u izvoznim proizvodima kao slabosti cijelog sistema. ${ }^{48} \mathrm{U}$ trećem slučaju određivanje razvijene organizacije za podršku poduzetništvu kao snage protivrječi tvrdnji da je nedovoljan broj naučnoistraživačkih centara i centara za sticanje vještina slabost našeg inovacionog sistema. ${ }^{49}$ Napokon, kao četvrti slučaj ističe se snaga koja se ogleda u dobroj saradnji privrednih subjekata i univerziteta koja se ne može se pomiriti sa više puta istaknutom slabošću u ovim odnosima industrija - univerzitet i nedostacima u operacionalizaciji Triple Helix modela. ${ }^{50}$ Navedene protivrječnosti mogu se dijelom objasniti različitim ovlaštenjima, ciljevima i politikama stvaralaca strateških dokumenata. ${ }^{51}$ Ipak, uzete u cjelini i povezano sa prilikama i prijetnjama, kontradikcije ukazuju na nedovoljnu harmonizaciju inovacionih podsistema i nekoherentnost inovacionog sistema u Bosni i Hercegovini.

Elementi inovacionog sistema koje je SWOT analiza utvrdila kao osnovu strateškog planiranja odražavaju samo jedan dio stvarnog odnosa donosilaca razvojnih odluka prema inovacionom sistemu. Za potpunu sliku potrebno je utvrditi najvažnije elemente sistema nauke i transfera tehnologije koji se ne nalaze u ekstrapoliranoj SWOT matrici inovacionog sistema. $\mathrm{Na}$ njih se odnosi treća grupa zaključaka iz Tabele 1. Prvi značajan kompleks problema koji nisu ni spomenuti tiču se zakonske regulative. Efekti Okvirnog zakona o naučnoistraživačkoj djelatnosti na nivou Države, ${ }^{52}$ posljedice nepostojanje sistemskog zakona ove vrste u entitetu Federacija BiH i propuštanje šest kantona da donesu nove zakone o inovacionom sistemu nisu kvalifikovani kao generalna strateška slabost ili prilika za ostvarivanje ciljeva razvoja. Unutrašnji

\footnotetext{
${ }^{47}$ Uporediti tačke 1.2. i 1.4 sa tačkama 2.1. , 2.2. i 2.10 iz Tabele br. 1.

${ }^{48}$ Uporediti tačke 1.3. sa tačkama 2.2. i 2.7. iz Tabele br. 1.

${ }^{49}$ Uporediti tačke 1.8 sa tačkom 2.12. iz Tabele br. 1.

${ }^{50}$ Uporediti tačke 1.3. i 2.15. iz Tabele br. 1.

${ }^{51}$ Država BiH i entitet FBiH smatraju da su nedostali u zaštiti intelektualne svojine slabost BIH razvojnog i inovacionog sistema. Kantoni se na ovaj element uopšte ne osvrću (Vidjeti Tabelu br. 1, tačku 2.5)

${ }^{52}$ Okvirni zakon o osnovama naučno-istraživačke djelatnosti i koordinaciji unutrašnje i međunarodne naučno-istraživačke saradnje Bosne i Hercegovine (Analizu ovoga akta vidjeti kod Trifković, 2020b: 95 - 102).
} 
jaz u znanju očito nije u fokusu strateškog planiranja razvoja. Druga potpuno zanemarena oblast su strategije razvoja inovacionog sistema, kao jednog od stubova društva i ekonomije znanja. ${ }^{53}$ Njihovo donošenje nije zabranjeno i kada propisi šute o ovom pitanju. Ipak, zakonodavstvo države $\mathrm{BiH}$, entiteta RS i četiri kantona ${ }^{54}$ sadrži obavezu navedenih političko-teritorijalnih jedinica da usvoje strategije razvoja inovacionog sistema. Trenutno u državi, umjesto 14 postoje samo tri strategije inovacionog sistema u različitom proceduralnom statusu: $\mathrm{BiH}$, entitet RS i Kanton Sarajevo. Federacija i tri kantona, koji su u svoje zakonodavstvo unijeli obavezu donošenja sektorske strategije, nisu to učinili. ${ }^{55}$ Bez obzira na navedeno stanje, ekstrapolirana SWOT matrica inovacionog sistema potpuno ignoriše nepostojanje strategija i neažurnost onih koje u usvojene. Treće, odnos prema finansiranju inovacionog sistema je istinski test shvatanja njegove uloge u ostvarivanju strategije razvoja. Strategija razvoja Bosne i Hercegovine, ${ }^{56}$ istraživanja $^{57}$ i teorijski radovi pokazuju da je stanje u ovoj oblasti potpuno nezadovoljavajuće. Najvažniji nedostaci su: apsolutno neprihvatljivo nisko izdvajanje za ove svrhe - između $0,2 \%$ i 0,3\% BDP-a, dominacija budžetskog (su)finansiranja, usitnjenost i onako malih sredstava, administriranje raspodjelom za namjene i projekte, zamagljeno finansiranje nauke na univerzitetima, vremenska neusklađenost projektnih aktivnosti sa prilivom sredstava, nedovoljno ulaganje države u opremu, ${ }^{58}$ te izostanak carinskih i poreskih poticaja. Zbog toga začuđuje da se finansiranje inovacionog sistema ne pojavljuje ni u jednom od faktora SWOT analize opštih strategija razvoja. Umjesto toga, među elementima slabosti ekonomsko-finansijskog karaktera se nalaze oni za koje političkoteritorijalne jedinice nisu direktno odgovorne: nizak nivo dodatne vrijednosti u izvoznim proizvodima, nedovoljna direktna strana ulaganja i tehnološki transferi, slabe veze privrede i univerziteta u oblasti istraživanja, mali broj

\footnotetext{
${ }^{53}$ Trifković, 2020b: $23-25$ i $35-37$.

${ }^{54}$ Vidjeti Trifković, 2020b: 49-50

${ }^{55} \mathrm{O}$ pravnom režimu kantonalnih razvojnih strategija inovacionog sistema vidjeti: Trifković, 2020b:131 - 134 .

${ }^{56}$ „Strategija razvoja znanosti u Bosni i Hercegovini 2017.-2022. - revidirani okvirni dokument" Vijeće ministara BiH, 20.6.2016., str. 14 -17

${ }^{57}$ Trifković, 2020b: 64, 127 i 192.

${ }^{58}$ Agencija za statistiku Bosne i Hercegovine: „Saopćenje - Nauka, tehnologija i digitalno društvo: Istraživanje i razvoj 2019.“, podnaslov 2.1. navodi da je od 39.728.000 KM bruto sredstava uloženih u visoko obrazovanje, za investicione izdatke utrošeno samo 1.992 .000 KM ili 19,72\%. Iste godine poslovni sektor je u istraživanje i razvoj uložio 25.647.000 KM, od čega 9,871.000 KM ili 38,44\% za investicije.
} 
naučnoistraživačkih centara i nedostatak savremene opreme u svim oblastima. ${ }^{59}$ Četvrto, posljedica prešutkivanja problema finansiranja inovacionog sistema je potpuno ignorisanje fundamentalnih i razvojnih istraživanja kao instrumenata za rješavanje brojnih razvojnih slabosti i prijetnji, uključujući i one tehnološkog karaktera. ${ }^{60}$ U skladu s tim, ni ubrzano formiranje (samostalnih) instituta se ne vidi kao prilika koju nudi inovacioni sistem. Napokon, peto, jedino Zapadnohercegovačka županija smatra da je nepostojanje mehanizama motivacije državnih službenika za razvojne poslove opasnost po razvoj inovacionog sistema i ostvarivanje strategija razvoja. ${ }^{61}$ Dvanaest ostalih nosilaca planiranja zaobilaze ovaj problem, relativizirajući tako svoje obaveze iz programa reforme javne uprave. ${ }^{62}$

Sve tri grupe zaključaka baziranih na ekstrapoliranoj SWOT matrici strateškog planiranja daju osnova za pesimističan stav: različiti nivoi državne vlasti, svaki u svom djelokrugu, ne unose u razvojnu SWOT analizu elemente inovacionog sistema koji zahtijevaju njihovo dodatno finansijsko ili radno opterećenje. Posljedice ovakve politike nastoje se barem implicitno podijeliti sa ostalim subjektima sistema. Očito je da državna tijela ulaganje u istraživanje i razvoj tretiraju kao trošak, a ne investiciju. Time se hipoteza o inovacionom sistemu kao pastorčetu političko-teritorijalnih jedinica može smatrati dokazanom. Dvije su krajnje konsekvence postojećeg pristupa inovacionom sistemu: Bosna i Hercegovina se zadržava u grupi država koje svoj razvoj baziraju na efikasnosti iskorištavanja sirovina uz istovremeno usporavanje procesa stvaranja društva i ekonomije znanja.

\footnotetext{
${ }^{59}$ Vidjeti Tabelu br. 1, brojeve 2.2, 2.4, 2.7, 2.12 i 2.13. Od 209 istraživačkih projekata, koje je od 2016. do 2018, g. obavilo 18 instituta u entitetu $\mathrm{FBiH}, 13$ i 6,22\% otpada na fundamentalna, a 13 ili $6,22 \%$ na razvojna istraživanja. U isto vrijeme završena su 103 konzultantska projekt ili 49,28\% od ukupnog broja projekata (Vidjeti: Kremić \& Trifković, 2020: 29.).

${ }^{60}$ Vidjeti Tabelu br. 1, redne brojeve 2.1.-2.4.

${ }^{61}$ Vidjeti Tabelu br. 1, redni broj 2.16.

${ }^{62}$ Kremić \& Trifković, 2020:9-15 daje obilje podataka u prilog naše tvrdnje za područje FBiH. Od 111 federalnih i kantonalnih ministarstava obuhvaćenih istraživanjem 31 (27,93\%) nije uopšte odgovorilo na upitnik, $36(32,43 \%)$ je navelo da nemaju aktivnosti u oblasti inovacionog sistema, a $44(39,64 \%)$ su popunila upitnik. Prema sistematizaciji radnih mjesta u federalnim ministarstvima pet zaposlenih se bave pitanjima inovacionog sistema sa punim radnim vremenom i još tri sa pola radnog vremena. U kantonalnim ministarstvima koja su odgovorila na upitnik situacija je obrnuta. Šest zaposlenih radi do pola radnog vremena a samo jedan puno radno vrijeme na pitanjima inovacionog sistema. Od 44 ministarstva koja su odgovorila na upitnik, u četiri federalna i 19 kantonalnih ne postoji strategija naučnotehnološkog razvoja niti se na njoj radi. Samo je jedno federalno ministarstvo navelo da premijer vlade i resorni ministar redovno jednom mjesečno razmatraju stanje inovacionog sistema $\mathrm{i}$ visokog obrazovanja, itd.
} 
SWOT analize inovacionog sistema u strategijama razvoja nauke u Bosni i Hercegovini

U Bosni i Hercegovini trenutno postoje četiri dokumenta o strategiji razvoja inovacionog sistema za period do 2022. godine. To su: „Strategija razvoja nauke u Bosni i Hercegovini 2017-2022. - Revidirani okvirni dokument“, verzija 01, od 26. 6. 2016. godine, Vijeća Ministara ${ }^{63}$ (dalje: SRN BiH); „Strategija razvoja nauke u Federaciji Bosne i Hercegovine za period 2011 2021. godine (Nacrt)“64 (dalje: SRN FBiH), uz napomenu da ovaj dokument nije razmatran u Parlamentu $\mathrm{FBiH}$; ,Strategija naučnog i tehnološkog razvoja Republike Srpske 2017 - 2021. godine - 'Znanje za razvoj'“665, prijedlog iz aprila 2017, Vlada Republike Srpske (dalje: SNTR RS) i „Strategija razvoja obrazovanja i nauke Kantona Sarajevo za period 2018 - 2022. godine (Nacrt)“, Ministarstvo za obrazovanje, nauku i mlade Kantona Sarajevo, juni 2017. (dalje: SRON KS). ${ }^{66}$

Formalno-pravni položaj sektorskih strategija inovacionog sistema je različit. SRN BiH je usvojena i važi, SRN FBiH je napušteni dokument nejasnog juridičkog položaja, SRNT RS i SRON KS se nalaze u fazi nacrta. Bez obzira na pravni status dokumenta, podaci, analize i zaključci koje oni sadrže su stručno relevantni, pa ćemo ih uzeti u razmatranje. Ciljevi i oblasti za koje su strategije napisane i njihovi naslovi se donekle razlikuju. Strategija države inovacioni sistem posmatra kao cjelinu, dok je strategija RS najviše pažnje poklonila tehnološkoj komponenti. U strategiji Kantona Sarajevo pažnja je podijeljena između obrazovanja i nauke, ${ }^{67}$ SWOT matrice koje pojedine strategije sadrže odražavaju razlike u predmetu i naslovima prethodno spomenutih dokumenata. Pregled dajemo tabelarno.

\footnotetext{
${ }^{63}$ Službeni glasnik BiH, broj 22/18

${ }^{64}$ Federacija Bosne i Hercegovine. Federalno ministarstvo obrazovanja i nauke. (2010).

${ }^{65}$ Republika Srpska. Vlada Republike Srpske (2017).

${ }^{66}$ Kanton Sarajevo. Vlada Kantona Sarajevo. Ministarstvo za obrazovanje, nauku i mlade Kantona Sarajevo (2017). Nacrt je povučen sa 44. sjednice Skupštine KS 12. 10. 2018. g. ${ }^{67}$ Ibidem
} 
Tabela br. 2: Struktura SWOT matrice u sektorskim strategijama inovacionog sistema u BiH

\begin{tabular}{cccccc}
\hline \multirow{2}{*}{$\begin{array}{c}\text { R. } \\
\text { br. }\end{array}$} & Dokument o strategiji & \multicolumn{5}{c}{ Broj elemenata u faktorima SWOT matrice } \\
\cline { 3 - 6 } & & $\mathbf{S}$ & W & $\mathbf{0}$ & T \\
\hline $\mathbf{1}$ & $\mathbf{2}$ & $\mathbf{3}$ & $\mathbf{4}$ & $\mathbf{5}$ & $\mathbf{6}$ \\
\hline 1. & SRN BiH & 7 & 24 & 14 & 11 \\
\hline 2. & SRN FBiH & 8 & 24 & 14 & 11 \\
\hline 3. & SNTR RS & 5 & 7 & 6 & 7 \\
\hline 4. & SRON KS & $7(-3)$ & $19(-6)$ & $13(-4)$ & $8(-1)$ \\
\hline
\end{tabular}

Prethodna tabela zahtijeva izvjesne komentare. Najprije, samo dva elementa snage, tri elementa slabosti i dva elementa prilika iz matrice SRN FBiH nisu uključena u državnu SWOT analizu. Dakle, SWOT matrice države i entiteta $\mathrm{FBiH}$ su praktično identične, iako su pravljene za različite nadležnosti i okolnosti dvije političko-teritorijalne zajednice. Drugo, u svim matricama dominiraju slabosti. Ta osobina je najmanje izražena u entitetu RS. Treće, SNTR RS je najdosljednije sažela elemente svakog faktora. I četvrto, u redu br. 4, koji se odnosi na Kanton Sarajevo, brojevi u zagradama označavaju elemente pojedinog faktora koji se odnose isključivo na dio obrazovnog procesa bez faktičkog uticaja na inovacioni sistem. Oni, zbog toga, moraju biti isključeni iz analize inovacionog sistema u ovom kantonu.

Strategija razvoja nauke u Bosni i Hercegovini se zasniva na principu koordiniranog planiranja. Ona mora da ,ima opšti karakter i da predstavlja najmanji zajednički sadržalac involviranih interesa“ ${ }^{68}$ Zbog toga ne začuđuje da SRN BiH ima najveći broj elemenata svakog faktora SWOT matrice. Njihovo agregiranje, bez obzira na rizike uopštavanja, zahtijevaju metodologiju SWOT analize i potrebu upoređivanja matrica $\mathrm{BiH}$ i ostalih nivoa vlasti. Rezultate grupiranja dajemo tabelarno. U zagradama pored brojeva se nalaze redni brojevi pojedinih elemenata u matrici $\mathrm{BiH}$.

${ }^{68}$ Trifković, 2020b:101 
Miloš Trifković, Dženana Husremović: SWOT analiza inovacionog sistema u Bosni i Hercegovini

Tabela br. 3: „Agregirana SWOT matrica Strategije razvoja nauke Bosne i Hercegovine“

\begin{tabular}{cccccc}
\hline \multirow{2}{*}{$\begin{array}{c}\text { R. } \\
\text { br. }\end{array}$} & \multicolumn{1}{c}{$\begin{array}{c}\text { Agregirani } \\
\text { elementi }\end{array}$} & \multicolumn{4}{c}{ SWOT matrica Strategije razvoja nauke BiH } \\
\cline { 3 - 6 } & 2 & $\mathbf{S}$ & $\mathbf{W}$ & $\mathbf{0}$ & $\mathbf{T}$ \\
\hline 1 & & 3 & 4 & 5 & 6 \\
\hline 1. & Visoko školstvo i obrazovanje & $3(1,2,3)$ & $6(2,3,10,12,17,24)$ & $/$ & $/$ \\
\hline 2. & Organizacija i infrastruktura & $1(6)$ & $8(4,8,9,16,20,21)$ & $2(2,3)$, & $/$ \\
\hline 3. & Ekonomsko-finansijski elementi & $/$ & $4(18,19,22,23)$ & $4(1,8,10,14)$ & $3(2,3,11)$ \\
\hline 4. & Politički i kulturološki elementi & $/$ & $3(5,13,14)$ & $2(12,13)$ & $8(1,5,6,7,8,9,11)$ \\
\hline 5. & Međunarodna saradnja i ino-elementi & $1(4)$ & $3(1,6,15)$ & $6(4,5,6,7,9)$ & $/$ \\
\hline 6. & 0stalo & $2(5,7)$ & $/$ & $/$ & $/$ \\
\hline
\end{tabular}

Bez obzira na greške koje su inherentne klasifikaciji polivalentnih elemenata, gornja tabela pruža priliku za veliki broj pitanja i komentara. Zadržaćemo se na suštinskim. Najprije, element visokog obrazovanja je određen protivrječno: nasuprot tri elementa snage stoji čak šest elementa slabosti. Pri tome začuđuje da u faktorima prilika i prijetnji uopšte nema elemenata koji se vežu za visokoškolsko obrazovanje. Drugo, stanje organizacije i infrastrukture inovacionog sistema je tačno identifikovano. Ono pokazuje najveći broj slabosti, čak osam i samo dvije prilike. Značajno je da su nedostaci u finansiranju jasno istaknuti. Iznenađuje, međutim, da se negativne posljedice nedostatka sredstava nisu identifikovane kao prijetnje. Treće, ekonomski i finansijski nedostaci inovacionog sistema su precizno utvrđeni. Iznenađuje da se kao prilika navodi „,kompetitivna cijena naučnoistraživakog rada u $\mathrm{BiH}$ u poređenju sa inozemstvom“ ${ }^{69}$ kada se zna da je to jedan od glavnih razloga za brain drain. Pored toga, sedam od 14 prilika su na neki način povezane sa međunarodnom konkurencijom, iako u njoj domaći subjekti u principu imaju slabiji položaj. Četvrto, među politološkim i kulturološkim elementima s pravom su istaknuti kao ključne slabosti: dugogodišnja marginalizacija nauke, demotivacioni egalitarizam i oportunizam u ocjenjivanju rezultata naučnoistraživačkog rada. Među prijetnjama tri elementa imaju ekonomsku provenijenciju, ${ }^{70}$ a čak sedam njih - kulturološku. ${ }^{71}$ Provjera tačnosti tvrdnje o značaju kulturoloških prijetnji inovacionom sistemu u BiH zaslužuje

\footnotetext{
${ }^{69}$ SWOT matrica u SRN BiH, prilika br. 8

${ }^{70}$ SWOT matrica u SRN BiH navodi slijedeće ekonomske prijetnje: 2- loša poslovna svijest vlasnika kapitala; 3 - nastavak marginalizacije nauke na svim nivoima; 9 - pojava političkih intervencija u nauci; 11 - očekivanje od države da riješi sve probleme brain waste i barin drain u državi i u dijaspori

${ }^{71}$ SWOT matrica u SRN BiH, kulturološke prijetnje: 1 - nerazumijevanje važnosti RTD za razvoj zemlje; 4 - nesklonost promjenama, strah od rizika i neuspjeha; 6 - nepostojanje kul-
} 
posebno istraživanje. I peto, elementi koji uključuju međunarodnu saradnju i druge odnose sa elementom inostranosti najbrojniji su u faktoru prilike. Oni čine šest od 14 elemenata, što indicira nepovjerenje u domaće šanse.

Donošenje strategije razvoja inovacionog sistema u Republici Srpskoj uređeno je entitetskim Zakonom o naučnoistraživačkoj djelatnosti i tehnološkom razvoju. ${ }^{72} \mathrm{Na}$ toj osnovi usvojena je i aktualna petogodišnja strategija naučno-tehnološkog razvoja, nazvana i „Znanje za razvoj“. Nakon razmatranja bitnih izazova, „Znanje za razvoj“ izlože šest osnovnih strateških ciljeva koji u jednakoj mjeri važe za sve subjekte i sve segmente inovacionog sistema. ${ }^{73}$ U oblasti nauke i inovativnosti svaki od njih može imati posebne pojavne oblike. Strategija polazi od pretpostavke da je institucionalni sistem „ključni preduslov za podsticanje inovacija“" ${ }^{74}$ a pri određivanju elemenata pojedinih faktora insistira na onima koji su zajednički u svim segmentima i subjektima inovacionog sistema. Rezultat ovakvog pristupa je i SWOT matrica. ${ }^{75} \mathrm{Njene}$ najupadljivije metodološke osobine su: mali broj elemenata u svakom faktoru - najviše sedam i jasna sadržinska veza između faktora prednosti i mogućnosti, te slabosti i opasnosti.

Entitet $\mathrm{FBiH}$ iz ustavnih i pravno-političkih razloga nije donio novi zakon o naučno-istraživačkoj djelatnosti. ${ }^{76} \mathrm{Iz}$ istih razloga je propao pokušaj da se donese entitetska strategija razvoja inovacionog sistema. Time su kantoni ostali jedini nosioci strateškog planiranja u ovoj oblasti. Njihova reakcija na ovaj zadatak je neujednačena. ${ }^{77}$ Do 2020 . godine svi su kantoni donijeli svoje zakone o visokom obrazovanju. Njima je uređen i dio inovacionog sistema koji se odvija u visokom školstvu. ${ }^{78}$ Zakone o naučnoistraživačkoj djelatnosti, koji regulišu najveći dio odnosa inovacionog sistema, promulgiralo je samo četiri kantona: Sarajevski, Zeničko-dobojski, Tuzlanski i Kanton 10. Ti zakoni uredili su i donošenje strategije razvoja naučnoistraživačke djelatnosti, odnosno inovacionog sistema. ${ }^{79}$ Od šest kantona koji nisu usvojili

ture cjeloživotnog učenja; 7 - nerazumijevanje posljedica odliva kadrova; 7 - izbjegavanje međunarodne konkurencije i zatvaranje u nacionalne okvire

${ }^{72}$ Službeni glasnik Republike Srpske 6/12, 33/14 66/18 i 84/19. O osnovnim principima vidjeti Trifković, 2020b: $194-195$.

${ }^{73}$ Vidjeti ZNTR RS str. $26-42$

${ }^{74}$ ZNTR RS, str. 6

${ }^{75}$ ZNTR RS, str. 45

${ }^{76}$ Vidjeti Trifković, 2020b: 106 - 107. Detaljna analiza stanja nalazi se u Trifković, 2020a: $46-48$

${ }^{77}$ Vidjeti Trifković, 2020b: $107-108$

${ }^{78}$ Vidjeti Trifković, 2020b: 169 -171.

${ }^{79}$ Vidjeti Trifković, 2020b:131 - 134. 
nove zakone o naučnoistraživačkoj djelatnosti bilo bi suviše očekivati izradu srednjeročnih strategija razvoja inovacionog sistema. Ono što iznenađuje je nepostojanje strategija razvoja inovacionog sistema u tri kantona koji su ovu materiju zakonodavno uredili. Utoliko je važnije makar i djelomično planiranje ove materije u opštim kantonalnim strategijama razvoja. ${ }^{80}$

SWOT matrica koju sadrži Strategija razvoja obrazovanja i nauke Kantona Sarajevo donesena je na osnovu čl. 46, st. 1 Zakona o visokom obrazovanju KS. Time se vjerovatno može objasniti činjenica da ova strategija lavovskim dijelom obuhvata poslove iz nadležnosti kantonalnog ministarstva, a ne ukupnost inovacionog sistema na relevantnom području. Posljedice su dvostruke. Najprije, elementima visokoškolske nastave koji samo indirektno mogu biti značajni za cijeli inovacioni sistem posvećena je značajna pažnja. Njih ćemo $\mathrm{u}$ analizi izostaviti. I drugo, fokus strategije je na nauci koja se stvara na univerzitetu. Ostala otvorena pitanja inovacionog sistema, tehnološkog razvoja posebno, nisu ni spomenuta u SWOT analizi. Shodno tome, elemente snage SRON KS nalazi isključivo u visokom obrazovanju. ${ }^{81}$ Faktor slabosti je i u ovoj matrici najobimniji. Od 14 elemenata relevantnih za inovacioni sistem njih šest se tiče kadrova, ${ }^{82}$ šest se odnosi na organizaciju funkcionisanja sistema ${ }^{83}$ a samo dva na finansiranje i to isključivo naučnog osoblja i njihovog naučno-istraživačkog rada. ${ }^{84}$ Prvih šest prilika, već tradicionalno, vide se u međunarodnoj saradnji i to gotovo isključivo u oblasti nastave. Saradnja sa našom naučnom dijasporom trebalo bi da se odvija na istom konceptu. ${ }^{85}$ Od ostalih elemenata ovoga faktora Strategija navodi se jedino "saradnju sa poslovnom zajednicom i realizaciju konkretnih stručnih i aplikativnih projekata“. ${ }^{86}$ Prijetnje su najkontradiktorniji faktor ove matrice. Najprije, nedovoljno finansiranje naučno-istraživačkog rada i profesionalnog razvoja

\footnotetext{
${ }^{80}$ Kremić \& Trifković, 2020:11. Sugeriše da u FBiH zaposleni u ministarstvima nisu u dovoljnoj mjeri kreatori strategije. Od 14 uposlenih samo dva „pripremaju nacrt strategije“. Dva uposlena rade na pripremi podloga, pet radi isključivo administrativne poslove, a pet „daju primjedbe i mišljenja“.

${ }^{81}$ SRON KS: 1 - imidž i tradicija visokog obrazovanja i naučno-istraživačkog rada; 2 - raznovrsnost naučnih grupacija i 3 - akreditovane visokoškolske ustanove.

${ }^{82}$ SRON KS: Slabosti, tačke 2 - 7. Interesantno je da se slabosti vide u: nedostatku specifičnih vještina pisanja domaćih i međunarodnih projekata, neprepoznatljivosti u realizaciji stručnih i aplikativnih projekata, nedovoljnoj orijentiranosti i motiviranosti, te u nedovoljnom publikovanju Web of Science u odnosu na zemlje iz okruženja.

${ }^{83}$ SRON KS: Slabosti, tačke 1, 10,13, 15, 16 i 19.

${ }^{84}$ SRON KS: Slabosti: tačke 8. i 9.

${ }^{85}$ SRON KS: Prilike, tačka 10.

${ }^{86}$ SRON KS: Prilike, tačka 9.
} 
akademskog osoblja se tretira kao slabost i kao prijetnja ${ }^{87}$ Dalje, u skladu $\mathrm{s}$ administrativnom provenijencijom SRON KS, aktuelna „ograničenost dostupnih izvora finansiranja“" ${ }^{\text {“8 }} \mathrm{i}$,,sistemska neizvjesnost u smislu neizvjesnog finansiranja ${ }^{\text {"89 }}$ su tek buduće prijetnje, a ne bitna aktualna slabost inovacionog sistema u Kantonu Sarajevo. Napokon, ,,neadekvatan imidž univerziteta i visokoškolskih ustanova u javnosti ${ }^{\text {“90 }}$ direktno je suprotan snazi imidža i tradicije u sarajevskoj regiji. ${ }^{91}$ Od ostalih elemenata ovoga faktora treba istaći pravilno uočenu opasnost koju po inovacioni sistem predstavljaju nepostojeći ili neusklađeni zakonski propisi, strategije i politike. ${ }^{92}$

\section{SWOT analiza aktualnog stanja inovacionog sistema u Bosni i Hercegovini}

Novija istraživanja inovacionog sistema u Bosni i Hercegovini i način korištenja njihovih rezultata

Šest od 13 dokumenata opšteg strategijskog planiranja razvoja i sve tri sektorske strategije razvoja inovacionog sistema u $\mathrm{BiH}$, koje smo ispitivali $\mathrm{u}$ ovom radu, objavljeni su u periodu 2015-2017. godine. To znači da su podaci na kojima se utvrđuju elementi pojedinih faktora SWOT analize i zasnivaju strategije stari barem četiri do pet godina. Ove činjenice zahtijevaju da se SWOT analiza našeg inovacionog sistema uradi na bazi skorašnjih istraživanja, statističkih i drugih podataka. Od novih izvora koristili smo naročito istraživanja koje je ANUBiH provela samostalno ili sa drugim pravnim i fizičkim licima, ${ }^{93}$ nove statističke izvještaje i dokumente subjekata koji se profesionalno bave ovom oblašću. ${ }^{94}$

Postojeće SWOT analize su pokazale je da izbor elemenata pojedinih faktora ne smije biti zasnovan primarno na iskustvu, ${ }^{95}$ da SWOT matrica ne

\footnotetext{
${ }^{87}$ Uporediti SRON KS: Slabosti, tačke 9. i 10. s Prijetnjama, tačke 13. i 14.

${ }^{88}$ SRON KS; Prijetnje, tačka 2.

${ }^{89}$ SRON KS; Prijetnje, tačka 1.

${ }^{90}$ SRON KS: Prijetnje, tačka 8.

${ }^{91}$ SRON KS: Snage, tačka 1.

${ }^{92}$ SRON KS: Prijetnje, tačke 1. i 6.

${ }^{93}$ Cvitković, 2017., Trifković, 2020b, Kremić \& Trifković, 2020, Čičić; Trifković, 2020a: 39 -53;

${ }^{94}$ Vidjeti dio rada o visokoškolskom obrazovanju kao faktoru snage.

${ }^{95}$ Fleisher \& Bensoussan, 2007: 91-93, navode da je potrebno mnogo „pronicljivog rada“ da bi se na postavljena pitanja odgovorilo na pravi način i u perspektivi.
} 
može biti reducirana na listu elemenata svakog od njena četiri faktora i da formulacije pojedinih elemenata bitno utiču na njihovu poziciju u matrici. Takvi postupci u stvarnosti vode: izostavljanju značajnih elemenata pojedinih faktora, suštinskim kontradikcijama, pojavljivanju istog elementa unutar različitih faktora i - u krajnjoj liniji - manipulaciji ovom metodologijom.

Da bismo makar djelomično izbjegli navedene opasnosti najprije dajemo sažetu SWOT matricu inovacionog sistema u BiH sa minimalnim brojem najvažnijih elemenata svakog faktora. Ovakva matrica je po definiciji uopštena i samo relativno tačna. Zbog toga ona mora biti dopunjena konkretnim elementima do mjere koja sliku odnosa čini jasnom, a SWOT matricu operativnim dokumentom strateškog planiranja. Učinićemo to pridružujući faktoru snage i njegovim elementima suštinski povezane elemente drugih faktora.

Sažeta i razrađena SWOT matrica inovacionog sistema u Bosni i Hercegovini

Sažeta SWOT matrica oslanja se na elemente svakog faktora koji su nužni da bi se dobio relativno tačan makro pogled na stanje inovacionog sistema $u$ $\mathrm{BiH}$. Izrazito visoki nivo uopštavanja elemenata svakog faktora dozvolio je njihovo samo djelomično povezivanje u matrici. Element nekog od faktora koji u drugim faktorima nema svoj neposredan pandan - loš sistem finansiranja i nepostojanje sređenih etičkih pravila, na primjer - djeluje prema svim drugim faktorima podjednako.

Tabela br. 4: Sažeta SWOT matrica inovacionog sistema u Bosni i Hercegovini

\begin{tabular}{cccl}
\hline \multicolumn{2}{c}{ Faktori } \\
\hline R. br. & \multicolumn{2}{l}{ R. br. } \\
\hline $\mathbf{1}$ & $\mathbf{2}$ & $\mathbf{3}$ & $\mathbf{4}$ \\
\hline 1. & Snage & $\mathbf{2 .}$ & \multicolumn{1}{c}{ Slabosti } \\
\hline 1.1. & $\begin{array}{l}\text { Uspostavljen državni okvir za } \\
\text { inovacioni sistem }\end{array}$ & 2.1. & $\begin{array}{l}\text { Na bazi pretpostavke nadležnosti nižih političko-teritorijalnih } \\
\text { jedinica izrazito decentralizovan inovacioni sistem koji znači i } \\
\text { pasivizaciju državnih organa u ovom domenu }\end{array}$ \\
\hline 1.2. & $\begin{array}{l}\text { Ista osnovna organizaciona } \\
\text { struktura inovacionog sistema }\end{array}$ & 2.2. & $\begin{array}{l}\text { Pravne praznine i različita pravna rješenja za niz važnih } \\
\text { pitanja uspostave i funkcionisanja inovacionih podsistema } \\
\text { nižih političko-teritorijalnih jedinica }\end{array}$ \\
\hline 1.3. & Dobro stanje ljudskog kapitala & & $\begin{array}{l}\text { Pad nataliteta, smanjivanje broja đaka i studenata, problemi } \\
\text { u STEM obrazovanju, emigracija, odliv pameti }\end{array}$ \\
\hline
\end{tabular}




\begin{tabular}{|c|c|c|c|}
\hline 1.4. & $\begin{array}{l}\text { Ujednačeno i stabilizirano visoko } \\
\text { obrazovanje }\end{array}$ & 2.4. & $\begin{array}{l}\text { Apsolutno nedovoljno, dominantno budžetsko i po strukturi } \\
\text { neadekvatno finansiranje inovacionog sistema, uključujući i } \\
\text { visoko obrazovanje, }\end{array}$ \\
\hline 1.5 . & I & 2.5 & $\begin{array}{l}\text { Razmrvljen i nepotpun etički regulatorni sistem u oblasti } \\
\text { naučnih istraživanja razvoja tehnologije }\end{array}$ \\
\hline 1.6. & I & 2.6 & $\begin{array}{l}\text { Parcijaliziran sistem međunarodne saradnje, nedovoljna } \\
\text { naučna produktivnost i nezadovoljavajuće međunarodno } \\
\text { rangiranje domaćih univerziteta }\end{array}$ \\
\hline 3. & Prilike & 4. & Prijetnje \\
\hline 3.1. & $\begin{array}{l}\text { Jačanje zainteresovanosti državnih } \\
\text { organa, ministarstava posebno, za } \\
\text { popunjavanje pravnih praznina, } \\
\text { planiranje rada, funkcionisanje i } \\
\text { korištenje inovacionog sistema }\end{array}$ & 4.1. & $\begin{array}{l}\text { Zanemarivanje nadležnosti u oblasti inovacionog sistema } \\
\text { od strane državnih organa i inertnost organa nižih političko- } \\
\text { teritorijalnih jedinica na usavršavanju i boljem funkcioniranju } \\
\text { inovacionog sistema. }\end{array}$ \\
\hline 3.2. & $\begin{array}{l}\text { Harmonizacija zakonodavstva i } \\
\text { podzakonskih akta, donošenje } \\
\text { usaglašenih strategija razvoja }\end{array}$ & 4.2 . & $\begin{array}{l}\text { Izostanak harmonizacije legislative, zadržavanje pravnih } \\
\text { praznina u FBiH, nedostatnost strategija, te dalje } \\
\text { produbljivanje spoljnjeg i unutrašnjeg jaza u znanju }\end{array}$ \\
\hline 3.3. & $\begin{array}{l}\text { Sistematičan rad na povezivanju } \\
\text { visokoškolskih ustanova, privrede i } \\
\text { državnih organa u istraživanjima i } \\
\text { razvoju tehnologija }\end{array}$ & 4.3. & $\begin{array}{l}\text { Zadržavanje postojećeg neprimjernog nivoa i kvaliteta } \\
\text { saradnje univerziteta i privrede uz stagnaciju sistema i prakse } \\
\text { transfera tehnologije iz inostranstva posebno }\end{array}$ \\
\hline 3.4. & $\begin{array}{l}\text { Donošenje multidisciplinarne } \\
\text { strategije ili programa očuvanja i } \\
\text { razvoja ljudskog kapitala }\end{array}$ & 4.4. & $\begin{array}{l}\text { Zadržavanje dominacije budžetskog i birokratiziranog } \\
\text { finansiranja istraživačkog rada i razvoja tehnologije, čija je } \\
\text { posljedica pogoršanje globalne konkurentnosti BiH }\end{array}$ \\
\hline 3.5. & I & 4.5. & $\begin{array}{l}\text { Izostanak strategija i mjera za povećanje nataliteta, } \\
\text { smanjivanje emigracije i odliv pameti iz BiH. }\end{array}$ \\
\hline
\end{tabular}

Iz prethodne tabele se vidi da slabosti ponovo dominiraju. Odnos faktora rizika i šansi je 11:8, čime je potvrđena opšta zakonitost u ovom domenu. Suprotno tome, bliže ispitivanje elemenata snage pokazuje značajno odstupanje uobičajenog stanja. Četiri elementa snage su u stvari temeljni uslovi za postojanje bilo kakvog, a ne samo dobrog inovacionog sistema. Paradoksalno, izgleda da je najveća snaga našeg inovacionog sistema u tome što je njegovo postojanje - moguće! Ovakav stav zahtijeva provjeru razradom sažete matrice prema elementima faktora snage. To prikazuje Tabela br. 5, koja se nalazi u Prilogu 2. Ona pruža relativno cjelovit uvid u skup činilaca koje određuju realan uticaj faktora snage, kao i ,sistemsko podudaranje ${ }^{\text {‘96 }}$ elementa snage sa elementima drugih faktora.Prva dva razrađena elementa snage u SWOT matrici iz Tabele br. 5. su političke i pravne prirode. Njihova

\footnotetext{
${ }^{96}$ Fleisher \& Bensoussan, 2007: 87-102
} 
normativna struktura i stvarni način funkcionisanja mogu se smatrati dovoljno poznatim. ${ }^{97}$ Treći element snage, „Dobro stanje ljudskog kapitala“, ima

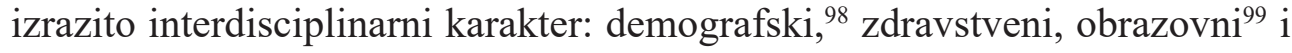
ekonomski. ${ }^{100}$ Rezultanta djelovanja raznorodnih činilaca u ovom slučaju daje proturječan rezultat. Složenost izvoznih proizvoda u periodu 2010. - 2018. godine svrstava Bosnu i Hercegovinu između 33. i 40. mjesta, tj. u ,više rangirane zemlje“" što indicira razvijen ljudski kapital. Nasuprot tome stoji iz matrice jasno uočljiv trend pogoršanja stanja svih činilaca vrijednosti ljudskog kapitala. ${ }^{101}$ Vrlo je vjerovatno da će negativne demografske tendencije ${ }^{102}$ multiplicirati učinke faktora slabosti i ubrzati pretvaranje pojedinih prijetnji u aktualne probleme. Iz ovoga nužno proizlazi zaključak da je sveobuhvatno istraživanje stanja ljudskog kapitala u Bosni i Hercegovini neophodno.

Analizirane SWOT matrice bez izuzetka tretiraju visoko obrazovanje kao faktor snage. Visokoškolske ustanove su najvažniji stvaralac kodificiranog znanja i naučnoistraživakog kadra u Bosni i Hercegovini, pa kvalitet njihovog rada bitno utiče na ostale elemente ostalih faktora. Preko tih elemenata visoko školstvo suštinski određuje razvojni kapacitet i dinamiku inovacionog sistema u cjelini. Zbog toga ćemo ovaj element faktora snage detaljnije ispitati.

\footnotetext{
${ }^{97} \mathrm{Za}$ pravni okvir vidjeti Trifković, 2020 b: 95 - 106, i 168 - 188. U ovom radu razmatrali smo strategije razvoja. Odgovori Bosne i Hercegovine na „Upitnik Evropske komisije“, Poglavlje 25: „Nauka i istraživanje“ sadrže oficijelne stavove o inovacionom sistemu. Za prva tri činioca slabosti, koji se odnose na ustavni položaj države, vidjeti i Trifković, 2020a. Kritiku načina finansiranja inovacionog sistema izložili smo u ovom radu, dio: Elementi SWOT analize inovacionog sistema u strateškim razvojnim dokumentima u Bosni i Hercegovini.

${ }^{98}$ Emirhafizović \& Zolić, 2017: 11 - 54. zaključuju da su rat u BiH 1992 -1995 i društveni trendovi nakon njega ,,izokrenuli sve trendove u demografiji bosanskohercegovačkog stanovništva".

${ }^{99}$ Pašalić - Kreso, 2017:93 - 124

${ }^{100}$ Globalni ekonomski indeksi koji različitim indikatorima prate stanje ljudskog kapitala u Bosni i Hercegovini nisu međusobno ujednačeni. Ipak, rezultati devetogodišnjeg razvoja, koje priprema Svjetska Banka su porazni za našu državu. O tome vidjeti Trifković, 2020a: $53-55$.

${ }^{101}$ Vidjeti i Trifković, 2020a: 54

${ }^{102}$ Vidjeti Federalni zavod za statistiku. (2020): 7, Slika br. 1: „Uporedni pregled boja stanovnika 2019 -2070, Varijanta 1 i Varijanta 2“. Osnovano je pretpostaviti da je stanje slično i u entitetu Republika Srpska.
} 


\section{Ujednačeno i stabilizirano visoko obrazovanje}

Visoko obrazovanje je pravno najuređeniji element inovacionog sistema u Bosni i Hercegovini. ${ }^{103}$ Ono je sistemom međunarodnih konvencija i domaćom legislativom potpuno i ažurno uključeno u EHEA. Planiranje razvoja se ostvaruje opštim i sektorskim strategijama. Bez obzira na različite nivoe ostvarenja juridičkih i strategijskih dokumenata, postojanje planskih akata je bitno uticalo na društvene odnose u ovoj oblasti. Stvarno stanje visokog obrazovanja kao ključne pokretačke snage inovacionog sistema ispitaćemo povezujući elemente njegove snage sa drugim faktorima SWOT matrice.

Prvi element faktora snage je veliki broj raznovrsnih visokoškolskih ustanova. Među njima se nalaze javne i privatni univerziteti. Uprkos neujednačenoj terminologiji i različitom broju evidentiranih privatnih ustanova generalna slika je jasna: postoji osam (8) javnih univerziteta i između 19 i 34 privatne visokoškolske ustanove. ${ }^{104}$ Podaci koje ćemo kasnije prezentirati dokazuju da dominacija brojem ne znači i dominaciju kvalitetom. Drugo, zahvaljujući pretežno javnim univerzitetima, na visokoškolskim ustanovama u Bosni i Hercegovini se izučavaju sve naučne i umjetničke oblasti. Obrazovne potrebe i ekonomska situacija dovele su do toga da danas nemamo univerzitete koji su pretežno orijentirani na neku posebnu naučnu oblast. Tome doprinosi i činjenica da Okvirni zakon za status unviverziteta zahtijeva da se na instituciji

\footnotetext{
${ }^{103}$ Trifković, 2020b: 103-106, 168-172, 213-216

${ }^{104}$ Prema evidenciji akreditiranih visokoškolskih ustanova koju ažurira Agencija za razvoj visokog obrazovanja i osiguranje kvaliteta Bosne i Hercegovine, u Bosni i Hercegovini djeluje osam (8) javnih visokoškolskih ustanova i dvadeset četiri (24) privatne visokoškolske ustanove. Na listi visokoškolskih ustanova koje ažurira Centar za informiranje i priznavanje dokumenata iz oblasti visokog obrazovanja Bosne i Hercegovine (vidjeti Bosna i Hercegovina. Centar za informiranje i priznavanje dokumenata iz oblasti visokog obrazovanja Bosne i Hercegovine, 2021) nalazi se osam (8) javnih visokoškolskih ustanova i trideset četiri (34) privatne visokoškolske ustanove, što predstavlja razliku od deset (10) visokoškolskih ustanova u odnosu na prethodni izvor podataka. Dalje, agencije za statistiku prikupljaju podatke o visokom obrazovanju koji se odnose na upisane i svršene studente, kao i angažirane nastavnike, dok sam broj visokoškolskih ustanova nije indiciran. Napokon, Federalni zavod za statistiku Federacije Bosne i Hercegovine u svojim statistikama visokog obrazovanja indicira postojanje devedeset dvije (92) visokoškolske ustanove, od čega sedamdeset (70) javnih, devetnaest (19) privatnih i tri (3) vjerske visokoškolske ustanove. Za razliku od prethodnog Saopštenja (03.03.2020. godine za školsku 2019/2020 godinu), u Statističkom biltenu visokog obrazovanja za 2019/2020 godinu navodi se postojanje šezdeset sedam (67) javnih fakulteta, pet (5) akademija, tri (3) vjerska fakulteta, sedam (7) visokih škola, te jedanaest (11) privatnih univerziteta. Republički zavod za statistiku Republike Srpske u svom biltenu visokog obrazovanja bilježi postojanje dvadeset (20) ustanova visokog obrazovanja, od čega devet (9) univerziteta i jedanaest (11) visokih škola ne navodeći tip ustanove (javna/privatna).
} 
izučava najmanje pet studijskih programa iz najmanje tri naučne oblasti. ${ }^{105}$ Isti društveni razlozi nisu pogodovali formiranju istraživačkih univerziteta, čiji je nedostatak jedna od značajnih slabosti našeg inovacionog sistema.

Indirektan zaključak o diversifikaciji obrazovnog i naučnoistraživakog rada može se donijeti na osnovu distribucije upisa studenata po pojedinim oblastima. Analiza podataka Federalnog zavoda za statistiku i Republičkog zavoda za statistiku RS o broju studenata upisanih na pojedine studijske programe razvrstane u šire naučne i umjetničke oblasti, pokazuje da se oko 55\% svih studenata školuje u oblastima društvenih i humanističkih nauka i umjetnosti. Oko 28\% studenata upisano je u STEM područjima (fundamentalne nauke, tehnička oblast, elektrotehnika i matematika), 21\% studenata se školuje o oblasti medicine i zdravstva, dok se $4 \%$ studenata nalazi u oblasti biotehničkih nauka (poljoprivreda, ribarstvo, šumarstvo i veterinarska medicina). Uzimajući u obzir strukturu ekonomije i društva, dominacija društvenih nauka jeste očekivana. Ipak, navedeni podaci ruše tezu po kojoj broj studenata u tradicionalnim STEM područjima bitnim za inovacije i tehničko-tehnološki razvoj, apsolutno ne zadovoljava. Problem se nalazi na drugom mjestu: veliki broj školovanih studenata u STEM i medicinskom području relativno jednostavno nalaze poslove izvan granica $\mathrm{BiH}$. Zbog toga ograničena mogućnost angažiranja ovih stručnjaka u zemlji i nedostatak politike sprečavanja odliva pameti i jesu uvrštene u ključne slabosti inovacionog sistema. Činjenica da školujemo zadovoljavajući broj studenata iz STEM područja ne znači nužno da će oni doprinijeti društvu i ekonomiji znanja u Bosni i Hercegovini. Rješavanje problema školovanja kadrova za druge države, međutim, leži izvan domena inovacionog sistema.

Drugi važan pokazatelj naučne orijentacije u nekoj državi je i broj objavljenih naučnih radova iz pojedinih oblasti. Za potrebe pregleda dominantnih istraživačkih polja djelovanja univerzitetâ u Bosni i Hercegovini informacije smo uzeli iz baze podataka Scopus, koja ima nešto širi obuhvat časopisa i duži vremenski raspon indeksiranih radova u odnosu na Web of Science. ${ }^{106}$ Pregledom je obuhvaćeno sedam javnih univerziteta u Bosni i Hercegovini, osim Univerziteta u Bihaću koji nema ni jedan indeksiran rad pod tom afilijacijom. Kategorije prikazane u Tabeli broj 6: „Pregled objavljenih radova u Scopus bazi podataka prema granama nauke i univerzitetima od 1951. do

\footnotetext{
${ }^{105}$ Čl. 10, st. 2, alineja 2 Okvirnog zakona o visokom obrazovanju u Bosni i Hercegovini)

${ }^{106}$ Dostup podacima je ograničen pretplatničkim ugovorom između Clarivate Analytics i Elseviera s Univerzitetom u Sarajevu kao nosiocem ugovora za pristup bazama podataka (Scopus od 1951. do danas; Web of Science od 1994. do danas)
} 
2021. godine“ odražavaju taksonomiju istraživačkih polja i oblasti prema kojoj se članci svrstavaju u Scopus bazi. „Scopus tabela“ se nalazi u prilog br. 2. Analiza Table br. 6. daje osnovu za nekoliko relevantnih zaključaka. Najprije, u ukupnoj strukturi radova razvrstanih po istraživačkim oblastima prednjače medicinske nauke, potom inženjerstvo, te kompjuterske nauke. Iz raspoloživih podataka o objavljenim radovima vidljivo je da na univerzitetima u Bosni i Hercegovini dominiraju medicinske i tehničke nauke, dok na trećem mjestu se nalaze prirodno-matematičke i biotehničke nauke. Dalje, nalaz se podudara sa podacima o STEM obrazovanju koje smo već iznijeli. Društvene i humanističke nauke nemaju tako intenzivnu produkciju, s tim što treba uzeti u obzir da je i predmet proučavanja u ovim disciplinama velikim dijelom društveno/ nacionalno relevantan, a ne nužno i internacionalno interesantan. Napokon, razumljivo je da Univerzitet u Sarajevu, kao naša najstarija i najveća visokoškolska ustanova ima i najbolje rezultate. Ipak, politika i strategija razvoja visokog obrazovanja bi morale sadržavati poluge za postupno srazmjerno približavanje učinka javih univerziteta. Jedna od najznačajnijih je postepena reforma sistema finansiranja i podizanje izdvajanja za visoko obrazovanje kao segmenta inovacionog sistema.

Drugi značajan element snage visokoga obrazovanja princip jedinstva naučnoistraživačkog rada i nastave. I on ima nekoliko pojavnih oblika. $\mathrm{Na}$ prvom mjestu je jednak tretman naučnoistraživačkih i nastavnih aktivnosti u ugovorima o radu akademskog osoblja. Kao primjer mogu poslužiti Standardi i normativi za obavljanje djelatnosti visokog obrazovanja na području Kantona Sarajevo. ${ }^{107}$ Tim aktom su najprije tvrđeni uslovi čije je ispunjavanje neophodno za obavljanje djelatnosti. ${ }^{108} \mathrm{Njima}$ je, dalje, precizirano da su nastavnici i saradnici dužni aktivno se baviti naučnoistraživačkim, odnosno umjetničkim djelatnošću 20 sati nedjeljno. Ostatak radne sedmice rezervisan je za nastavu, ispite i administraciju. Ipak, rezultati istraživanja pokazuju da odnos naučnog i nastavnog rada u praksi još nije izbalansiran, te da su nastavne aktivnosti dominantne u odnosu na naučni rad. ${ }^{109}$ Ova slabost je zasigurno posljedica izmjena nastavnih planova i programa, koje postojećem

\footnotetext{
${ }^{107}$ Kanton Sarajevo. Vlada kantona Sarajevo. Ministarstvo za obrazovanje, nauku i mlade Kantona Sarajevo Standardi i normativi za obavljanje djelatnosti visokog obrazovanja na području Kantona Sarajevo (2017)

${ }^{108}$ Standardima i normativima utvrđuju se minimalni kadrovski, prostorni i drugi materijalnotehnički uslovi neophodni za obavljanje djelatnosti visokog obrazovanja i naučnoistraživačkog/umjetničkoistraživačkog rada u skladu sa Okvirnim zakonom o visokom obrazovanju u Bosni i Hercegovini i kantonalnim Zakonom o visokom obrazovanju

${ }^{109}$ Kremić \& Trifković, 2020:21, tabele 2-7
} 
nastavnom kadru nameću i moralnu obavezu povećanog obima pedagoškog rada. Integracija nauke i nastave se vidi i iz angažovanosti studenata u naučnoistraživačkom radu ${ }^{110}$. Druga manifestacija jedinstva naučnog i nastavnog rada tiče se studenata. Polaznici prvog ciklusa najčešće se uključuju u manja istraživanja za potrebe nastave, dok se studenti drugog ciklusa, kao i studenti doktorskih studija samostalni nosioci istraživanja ili članovi projektnih timova koje vode nastavnici na nivou organizacionih jedinica, odnosno univerziteta. Uključivanje studenata $u$ istraživanja povećava njihove kompetencije potrebne za budući samostalni istraživački rad te zasigurno doprinositi i povećanju ljudskog kapitala u oblasti nauke u Bosni i Hercegovini. Napokon, institucionalizovani oblik bavljenja načnoistraživačkim radom na univerzitetima su instituti. ${ }^{111} \mathrm{U}$ zakonodavstvu entiteta FBiH status instituta imai organizaciona jedinica pravnoga lica sa pravom samostalnog nastupa na tržištu. Instituti integrisanih unvierziteta imaju takav položaj. Njihov položaj ima karakteristike dvostrukog pravnog režima: statusna pitanja se ravnaju prema mjerodavnom zakonu o visokom obrazovanju, a zvanja i način rada prema zakonima o naučnoistraživačkoj djelatnosti. Rad univerzitetskih instituta tek treba istražiti.

Naučni radnici nisu dovoljno brojni, niti zastupljeni u strukturi radne snage. ${ }^{112}$ Ipak, njihov najveći broj je koncentrisan na univerzitetima. ${ }^{113}$ Zbog tog je treći značajan element snage inovacionog sistema dobar naučnonastavni kadar. Na formalnom nivou, kvalitet nastavnog kadra diktiraju odredbe o uslovima za izbor akademskog osoblja u Okvirnom zakonu o visokom obrazovanju u $\mathrm{BiH}^{114}$ i način njihova adopcije zakonima nadležnih političko-teritorijalnih jedinica. Uporedni pregled pokazuje da u domaćem zakonodavstvu nema većih odstupanja od okvirnih odredbi Ta činjenica je s jedne strane refleksija objektivno nezadovoljavajućih uslova u kojima univerziteti rade, a sa druge strane može da upućuje na nedovoljno razvijenu autonomiju

\footnotetext{
${ }^{110}$ Kremić \& Trifković, 2020:21 tabele 2-8

${ }^{111}$ O pravnom statusu instituta u Bosni i Hercegovini vidjeti Trifković, 2020b: 45. Regulativa u entitetu FBiH je izložena na str. 145 - 147, a u entitetu RS na str. 203 - 206. Za Entitet RS vidjeti i čl. 47. i 64. Zakona o visokom obrazovanju RS.

${ }^{112}$ Trifković, 2020b: 42: godine 2015. oni su u u FBiH činili 0,47\%, a u RS 0,36\& ukupnog broja zaposlenih.

${ }^{113}$ Prema Agencija za statistiku Bosne i Hercegovine. Nauka, tehnologija i digitalno društvo, Statistika Istraživanje i razvoj 2019 od 2883 zaposlenih u istraživanju i razvoju godine 2019., njih 2271 je radilo u visokom obrazovanju. Od toga je istraživača bilo 1871, a tehničkog i ostalog osoblja 400. Zabrinjava podatak da je više od polovine istraživača (970) bilo angažovano sa radnim vremenom kraćim od punog radnog vremena.

${ }^{114}$ Vidjeti članove 28 - 35.
} 
univerziteta koja vodi mirenju sa minimalnim standardima. Neposredan sintetički izraz djelovanja svih faktora SWOT matrica na institucionalnom planu može biti i globalno vrednovanje bosanskohercegovačkih univerziteta. Trenutno ga moramo prikazati prema Webometrics rangiranju, ${ }^{115}$ navodeći samo opšti plasman: 1 . UNSA - 1675; 2. UNBL - 2658; 4.UNTZ - 3694; 5. IUS - 3786; 7. SVM - 4748; 8. UNZE - 5129 itd. Značajno je da se među prvih 10 univerziteta u Bosni i Hercegovini nalaze i četiri privatna univerziteta; 3. International University of Sarajevo - 3557; 6. IU Burch - 3979 ; 9. European University Brcko - 6109 i 10. SSST - 6166.

Iz dosadašnjih izlaganja je vidljivo da je bosanskohercegovačko visoko obrazovanje kao sistem, uz uvažavanje dejstva objektivno uslovljenih slabosti i sjajnih individualnih i institucionalnih dostignuća, tek počelo da planski radi na prihvaćanju kriterij izvrsnosti. Zbog toga se na ovu priliku našeg inovacionog sistema moramo posebno osvrnuti. Približavanje naučno-istraživačkih ustanova Evropskom prostoru istraživanja podrazumijeva razvijanja izvrsnosti u istraživanju, odnosno prepoznavanja ustanove kao centra izvrsnosti u istraživanju. Jedan od mehanizama koji je uspostavljen na evropskom nivou je dodjeljivanje nagrade ili loga „Izvrsnost u istraživanju““. ${ }^{116}$ Evropska komisija dodjeljuje ovaj logo kao javno priznanje istraživačkim institucijama koje razvijaju procese ujednačavanja politika zapošljavanja i razvoja karijera istraživača sa Poveljom i Kodeksom za istraživačke institucije ${ }^{117}$. Institucije koje dobiju pravo da koriste ovaj logo pokazuju predanost da implementiraju pravedan i transparentan proces zapošljavanja i unapređivanja istraživača. Da bi institucija dobila ovaj logo, koji se evaluira u redovnim ciklusima kroz unutarnje i vanjske procese, potrebno je izraditi Strategiju ljudskih resursa za istraživače (HRS4R) sa Akcionim planom, te ova dva dokumenta kao obavezna usvojiti na najvišim akademskim tijelima univerziteta. U ovom trenutku, samo tri univerziteta u Bosni i Hercegovini imaju pravo da nose logo „Izvrsnost u istraživanju“. To su Univerzitet u Banja Luci od aprila 2015. godine, Univerzitet u Istočnom Sarajevu od 2017. godine i Univerzitet u Sarajevu od 2019. godine. Poređenja radi, u Republici Hrvatskoj šest sveučilišta i osam naučnih instituta ima ovaj logo, dok su se u Srbiji četiri univerziteta kvalifikovala za ovu nagradu. Na prvi pogled se može činiti da ovaj logo nije direktno povezan sa izvrsnim istraživanjima. Ipak, uvidom u elemente Povelje i Kodeksa jasno je da Evropska Komisija izvrsnost u istraživanju

\footnotetext{
${ }^{115}$ Consejo Superior de Investigaciones Científicas (2021).

${ }^{116}$ Evropska Komisija. (2021).

${ }^{117}$ European Comission. (2019).
} 
veže za angažovanje izvrsnih naučnika, stvaranje okruženja u kojem oni mogu slobodno i društveno odgovorno raditi i udruživati svoje napore na stvaranju promjena baziranih na kvalitetnim istraživanjima.

\section{Zaključci}

1. SWOT analiza je u Bosni i Hercegovini široko prihvaćena kao instrument opšteg i sektorskog strateškog planiranja, uključujući i razvoj inovacionog sistema. Njena primjena u entitetu FBiH je je postala $\mathrm{i}$ pravno obavezna. Vjerovatno će uskoro steći isti status i u entitetu RS. Te činjenice zahtijevaju intenzivno bavljenje metodološkim pitanjima SWOT analize.

2. Inovacioni sistem u Bosni i Hercegovini djeluje u nepovoljnom unutrašnjem socijalnom, ekonomskom, političkom i pravnom okruženju. Državni izdaci za istraživanja i razvoj se suštinski smatraju troškom, a ne investicijom. Zbog toga tretman istraživanja i razvoja u SWOT analizama pripremljenim za opšte strateške dokumente ne odgovara potencijalima inovacionog sistema za ostvarivanje razvojnih ciljeva.

3. Donošenje strategija razvoja inovacionog sistema je u Bosni i Hercegovini zanemareno. Samo država Bosna i Hercegovina, entitet Republika Srpska i Kanton Sarajevo imaju važeće strategije i SWOT analize u ovoj oblasti. Ovakvo stanje je pouzdan pokazatelj nezadovoljavajućeg odnosa politike prema inovacionom sistemu, faktor produbljivanja unutrašnjeg jaza u znanju i nagovještaj pogoršavanju položaja Bosne i Hercegovine u međunarodnoj konkurenciji.

4. Upoređivanje naše SWOT analize inovacionog sistema, urađene na osnovu skorašnjih istraživanja, sa SWOT matricama iz dokumenata opšteg i sektorskog strateškog planiranja pokazuje značajnu podudarnost između njih. Razlike postoje naročito u izboru pojedinih elemenata svakog faktora, tretmanu finansiranja kao slabosti sistema, zastupljenosti tehnološkog razvoja i uticaja međunarodne suradnje na poboljšanje stanja inovacionog sistema.

5. U svim SWOT matricama su relativno dobro stanje visokog obrazovanja i ljudskog kapitala najvažnije snage inovacionog sistema. Ovakva unisonost ne postoji kod ostalih faktora.

6. Sve urađene SWOT matrice pokazuju da postojeći inovacioni sistem u Bosni i Hercegovini nije ni dovoljno razvijen, niti interesno, ciljno, normativno i funkcionalno povezan u mjeri koja bi od njega načinila 
odlučujući faktor kretanja prema društvu i ekonomiji znanja. Samim tim naš inovacioni sistem ne omogućava nacionalnoj privredi prelazak iz faze efikasnijeg korištenja sirovina u fazu proizvodnje dobara zasnovane na znanju

7. SWOT analiza inovacionog sistema u Bosni i Hercegovini pokazuje da je on činilac izrazito sporog i na različite načine ograničenog društvenog i ekonomskog napretka, što u globalnoj konkurenciji objektivno znači stagnaciju, donosno relativno nazadovanje u razvoju. 


\section{Prilog 1}

Tabela br. 1: Elementi inovacionog sistema u SWOT matricama razvojnih dokumenata

\begin{tabular}{|c|c|c|c|}
\hline $\begin{array}{l}\text { R. } \\
\text { br. }\end{array}$ & $\begin{array}{l}\text { Faktori SWOT } \\
\text { analize }\end{array}$ & $\begin{array}{l}\text { Elementi pojedinih } \\
\text { faktora SW0T analize }\end{array}$ & $\begin{array}{l}\text { Skraćeni naziv } \\
\text { dokumenta i stranica }\end{array}$ \\
\hline 1 & 2 & 3 & 4 \\
\hline 1, & SNAGE & & \\
\hline 1.1. & & $\begin{array}{l}\text { Visok kvalitet obrazovanja u oblasti matematike i prirodnih } \\
\text { nauka }\end{array}$ & SO za BiH, 31 \\
\hline 1.2. & & $\begin{array}{l}\text { Stabilna dostupnost naučnika i inženjera, kvalitetan } \\
\text { univerzitetski nastavni kadar }\end{array}$ & $\begin{array}{l}\text { SO za BiH, } 31 ; \\
\text { SR SBK, } 31\end{array}$ \\
\hline 1.3. & & $\begin{array}{l}\text { Saradnja između univerziteta i industrije u oblasti istraživanja } \\
\text { i razvoja }\end{array}$ & $\begin{array}{l}\text { SO za BiH, 31; } \\
\text { SR ZDK, } 236\end{array}$ \\
\hline 1.4. & & $\begin{array}{l}\text { Kvalificirani stručni kadrovi u raznim privrednim i društvenim } \\
\text { oblastima }\end{array}$ & $\begin{array}{l}\text { NSP TK, 226; } \\
\text { SR SBK, 30; } \\
\text { SR ZDK, 238; } \\
\text { SR BPK, } 44\end{array}$ \\
\hline 1.5. & & Rasprostranjenost upotrebe interneta & SO za BiH, 31 \\
\hline 1.6. & & Dinamičan i konkurentan IT sektor & SR FBiH, 151 \\
\hline 1.7. & & Akreditiran i razvijen sustav visokog obrazovanja & $\begin{array}{l}\text { SR ŽP, 49; } \\
\text { ISR USK, 111; } \\
\text { SR SBK,31; } \\
\text { SR ZDK, 236; } \\
\text { SR KS 296; } \\
\text { SR HNŽ, } 113\end{array}$ \\
\hline 1.8. & & Razvijene organizacije za podršku poduzetništvu & $\begin{array}{l}\text { SR ZDK, 236; } \\
\text { SR ŽZH } 56\end{array}$ \\
\hline 1.9. & & Zakonski okvir za djelovanje u naučno-istraživačkom radu & SR KS, 297 \\
\hline 1.10. & & Zaštićene oznake zemljopisnog podrijetla & SR ŽZH 56 \\
\hline 2. & SLABOSTI & & \\
\hline 2.1. & & $\begin{array}{l}\text { Tehnološki usmjerena preduzeća napuštaju BiH zbog nedostatka } \\
\text { visokokvalifikovane radne i istraživačke snage }\end{array}$ & $\mathrm{SR} \mathrm{BiH,} 7$ \\
\hline 2.2 . & & $\begin{array}{l}\text { Nizak nivo dodatne vrijednosti u izvoznim proizvodima; } \\
\text { nedovoljno razvijena kreativna industrija }\end{array}$ & $\begin{array}{l}\text { SO za BiH, } 31 ; \\
\text { SR ZDK, 236; } \\
\text { K 10, } 31\end{array}$ \\
\hline 2.3. & & $\begin{array}{l}\text { Nizak nivo tehnologije, marketinga, istraživanja i razvoja u } \\
\text { preduzećima, naročito onih za zeleni rast i malim i srednjim } \\
\text { preduzećima }\end{array}$ & $\begin{array}{l}\text { SO za BiH, } 31 ; \\
\text { SR ŽP, } 49 ; \\
\text { SR HNŽ, } 113\end{array}$ \\
\hline 2.4. & & Nedovoljan nivo ulaznih SDU i tehnoloških transfera & SO za BiH, 31 \\
\hline
\end{tabular}




\begin{tabular}{|c|c|c|c|}
\hline $\begin{array}{l}\text { R. } \\
\text { br. }\end{array}$ & $\begin{array}{l}\text { Faktori SWOT } \\
\text { analize }\end{array}$ & $\begin{array}{l}\text { Elementi pojedinih } \\
\text { faktora SWOT analize }\end{array}$ & $\begin{array}{c}\text { Skraćeni naziv } \\
\text { dokumenta i stranica }\end{array}$ \\
\hline 1 & 2 & 3 & 4 \\
\hline 2.5 . & & Nedostaci u zaštiti intelektualne svojine & $\begin{array}{l}\text { SO za BiH, 31; } \\
\text { SR FBiH, 152; }\end{array}$ \\
\hline 2.6. & & Nepostojanje strateškog okvira za razvoj digitalne ekonomije & $\begin{array}{l}\text { SR FBiH ,151; } \\
\text { SR ŽP, } 49\end{array}$ \\
\hline 2.7. & & $\begin{array}{l}\text { Nedovoljna uključenost privrede u istraživačko-razvojne } \\
\text { aktivnosti univerziteta }\end{array}$ & $\begin{array}{l}\text { SR FBiH, 152; } \\
\text { SR HNŽ, 111; } \\
\text { SR ŽZH } 57\end{array}$ \\
\hline 2.8. & & $\begin{array}{l}\text { Nepostojanje zakonskog i strateškog okvira i loša koordinacija } \\
\text { inovacionog sistema; nedovoljna koordinacija u upravljanju } \\
\text { razvojem; nedosljedna primjena zakona o naučnoistraživačkoj } \\
\text { djelatnosti. }\end{array}$ & $\begin{array}{l}\text { SR FBiH, } 152 \\
\text { ISR USK, 111; } \\
\text { SR ZDK, 239; } \\
\text { SR HNŽ, } 111\end{array}$ \\
\hline 2.9. & & Nepoticajna poreska politika za razvoj & SR FBiH, 152 \\
\hline 2.10. & & $\begin{array}{l}\text { Smanjen prirodni priraštaj stanovništva i odlazak u inostranstvo, } \\
\text { naročito mladih }\end{array}$ & $\begin{array}{l}\text { SR ŽP, } 49 ; \\
\text { SR ZDK, 236; } \\
\text { SR ZDK, 241; } \\
\text { SR KS, 300; } \\
\text { K 10, 32 }\end{array}$ \\
\hline 2.11. & & Nedovoljno ulaganje u kampus i obrazovnu infrastrukturu & NSP TK, 226 \\
\hline 2.12 . & & $\begin{array}{l}\text { Nedovoljan broj naučnoistraživačkih centara i centara za sticanje } \\
\text { praktičnih vještina }\end{array}$ & NSP TK, 226 \\
\hline 2.13. & & Nedostatak savremene opreme u svim oblastima & $\begin{array}{l}\text { NSPTK, 226-227; SR } \\
\text { ZDK, } 238\end{array}$ \\
\hline 2.14 . & & $\begin{array}{l}\text { Nedovoljno promovisanje i poticanje, inovacija, istraživanja i } \\
\text { razvoja }\end{array}$ & SR HNŽ, 110 \\
\hline 2.15 & & Slaba povezanost javnog, privatnog i visokoškolskog sektora & $\begin{array}{l}\text { SR HNŽ, 110; } \\
\text { SR ŽZH } 57\end{array}$ \\
\hline 2.16. & & $\begin{array}{l}\text { Nepostojanje mehanizma motivacije državnih službenika za } \\
\text { razvojne poslove }\end{array}$ & SR ŽZH 57 \\
\hline 3. & PRILIKE & & \\
\hline 3.1. & & Direktna strana ulaganja (u moderne tehnologije) & SR BiH, 9; \\
\hline 3.2. & & $\begin{array}{l}\text { Zamah četvrte industrijske revolucije i genetike. } \\
\text { Upotreba tehnologija koje ne štete okolišu }\end{array}$ & $\begin{array}{l}\text { SR FBiH, } 154 \\
\text { SR SBK, } 32\end{array}$ \\
\hline 3.3. & & $\begin{array}{l}\text { Saradnja privrede, akademske zajednice i vlade u istraživanjima } \\
\text { (Triple helix) i pametna specijalizacija }\end{array}$ & $\begin{array}{l}\text { SR FBiH, 155; } \\
\text { SR KS, } 300\end{array}$ \\
\hline 3.4. & & Razvoj STEM obrazovanja & SR FBiH, 155 \\
\hline 3.5. & & Globalni lanci vrijednosti i mogućnost pametne specijalizacije & SR ŽP, 51 \\
\hline 3.6. & & Razvoj naučno-tehnoloških parkova & NSP TK, 226 \\
\hline
\end{tabular}




\begin{tabular}{|c|c|c|c|}
\hline $\begin{array}{l}\text { R. } \\
\text { br. }\end{array}$ & $\begin{array}{l}\text { Faktori SWOT } \\
\text { analize }\end{array}$ & $\begin{array}{l}\text { Elementi pojedinih } \\
\text { faktora SWOT analize }\end{array}$ & $\begin{array}{l}\text { Skraćeni naziv } \\
\text { dokumenta i stranica }\end{array}$ \\
\hline 1 & 2 & 3 & 4 \\
\hline 3.7. & & Korištenje EU fondova za NI i IR rad & SR KS, 299 \\
\hline 4. & PRIJETNJE & & \\
\hline 4.1. & & $\begin{array}{l}\text { Odljev kadrova (odlazak obrazovanih i mladih) posebno u } \\
\text { globalno deficitarnim strukama, npr. medicinskoj }\end{array}$ & $\begin{array}{l}\text { SR BiH,8 } \\
\text { ISR USK, 112; } \\
\text { NSP TK, 226 i 228; } \\
\text { SR HNŽ, 111; } \\
\text { SR BPK 45 }\end{array}$ \\
\hline 4.2. & & $\begin{array}{l}\text { Prijetnja marginalizacije bh. privrede, nauke i društva; ulaganje } \\
\text { u zastarjele tehnologije }\end{array}$ & $\begin{array}{l}\text { SO za BiH, 32; } \\
\text { SR ZDK, 242-243 }\end{array}$ \\
\hline 4.3. & & $\begin{array}{l}\text { Neuspješnost u privlačenju direktnih stranih ulaganja i transferu } \\
\text { tehnologije }\end{array}$ & SO za BiH, 32 \\
\hline 4.4 . & & $\begin{array}{l}\text { Nedostatak prenosa novih znanja i stručne pomoći od naučnih } \\
\text { institucija posebno u poljoprivredi i adaptaciji na klimatske } \\
\text { promjene }\end{array}$ & SR ŽP, 51 \\
\hline 4.5 . & & Destimulativna poreska i carinska politika & ISR USK, 112 \\
\hline 4.6. & & Nedovoljni kapaciteti NI i IR centara & SR SBK, 32 \\
\hline 4.7. & & Slaba institucionalna podrška Nl aktivnostima & SR ZDK, 240 \\
\hline 4.8. & & Nizak stepen saradnje naučno-istraživačkih institucija i privrede & SR ZDK, 240 \\
\hline
\end{tabular}

\section{Legenda:}

1. SR BiH - „Strategija razvoja Bosne i Hercegovine, Radni dokument“, Vijeće ministara, $2010 .{ }^{118}$

2. SO za BiH - „Strateški okvir za Bosnu i Hercegovinu“, Vijeće ministara, 2015. ${ }^{119}$

3. SR FBiH - „Strategija razvoja Federacije Bosne i Hercegovine“, Vlada FBiH, 2020. ${ }^{120}$

4. SR ŽP - „Strategija razvija Županije Posavske $2021-2027 “$, Županija posavska, 2021. ${ }^{121}$

5. ISR USK - „Integrirana strategija razvoja Unsko-Sanskog kantona“, Vlada USK, 2014. ${ }^{122}$

6. NSP TK - „Nacrt strateške platforme razvoja Tuzlanskog kantona“, Vlada TK, 2015. ${ }^{123}$

7. SR SBK - „Strategija razvoj Srednjobosanskog kantona za period 2016 - 2020“, 2016. ${ }^{124}$

8. SR ZDK - „Strategija razvoja Zeničko-dobojskog kantona za period 2021 - 2027, Nacrt“, ZDK kanton, $2020^{125}$.

\footnotetext{
${ }^{118}$ Bosna i Hercegovina. Vijeće Ministara. (2010).

${ }^{119}$ Bosna i Hercegovina. Vijeće Ministara. (2015).

${ }^{120}$ Federacija Bosne i Hercegovine. Vlada Federacija Bosne i Hercegovine. (2020).

${ }^{121}$ Federacija Bosne i Hercegovine. Županija Posavska. (2021).

${ }^{122}$ Federacija Bosne i Hercegovine. Unsko-sanski kanton. (2014)

${ }^{123}$ Federacija Bosne i Hercegovine. Tuzlanski Kanton. (2015).

${ }^{124}$ Federacija Bosne i Hercegovine. Srednjobosanki kanton. (2016).

${ }^{125}$ Federacija Bosne i Hercegovine. Zeničko-dobojski kanton. (2020).
} 
9. SR KS - „Strategija razvoja Kantona Sarajevo, Nacrt - proširena verzija“. KS - Zavod za planiranje razvoja, 2020.126

10. SR HNŽ - „Strategija razvitka Hercegovačko-neretvanske županije za period 2021. 2027. - Nacrt strateške platforme , Vlada HNŽ, 2020. ${ }^{127}$

11. SR BPK - „, Strategija razvoja Bosansko-podrinjskog kantona Goražde za period 2016.2020. godine“", $2015^{128}$

12.SR ŽZH - „Strategija razvoja Županije Zapadnohercegovačke 2021 - 2027“, ŽZH, 2020. ${ }^{129}$

13. K 10 - „Strategija razvoja kantona $10 \mathrm{z}$ a period 2016 - 2020. godina, Nacrt“ $2015^{130}$

${ }^{126}$ Federacija Bosne i Hercegovine. Kanton Sarajevo. (2020).

${ }^{127}$ Federacija Bosne i Hercegovine. Hercegovačko-neretvanska županija. (2020)..

${ }^{128}$ Federacija Bosne i Hercegovine. Bosansko-podrinjski kanton Goražde. (2015)

${ }^{129}$ Federacija Bosne i Hercegovine. Županija Zapadnohercegovačka (2021).

${ }^{130}$ Federacija Bosne i Hercegovine. Kanton 10. (2015). 
Prilog br. 2

Tabela br. 5: SWOT matrica inovacionog sistema u Bosni i Hercegovini razrađena prema faktoru snage i njegovim elementima

\section{Razrada elemenata faktora snage sažete SWOT matrice:} Uspostavljen državni okvir za inovacioni sistem

\begin{tabular}{cccc}
\hline R.br. & \multicolumn{3}{c}{ R.br. } \\
\hline 1 & 2 & 3 & 4 \\
\hline 1. & Snage & 2. & Slabosti \\
\hline
\end{tabular}

1.1. Donesen je Okvirni zakon o osnovama načnoistraživačke djelatnosti i koordinaciji unutrašnje i međunarodne naučno-istraživačke saradnje (Sl.gl. BiH /09)

1.2. Sporazum o stabilizaciji i pridruživanju EU otvorio mogućnosti za pristup ERA
2.1. Država BiH je nadležna za međunarodne odnose inovacionog sistema, ali nema efikasne ustavne i zakonske instrumente za ispunjavanje dogovorenih obaveza i prava unutar zemlje.
2.2. Pretpostavka nadležnosti nižih političkoteritorijalnih jedinica za sve poslove koji nisu izričito ustavom dati višoj političko-teritorijalnoj jedinici

1.3. Donesena državna strategija razvoja NID

2.3. Izostavljanje opšteg i parcijalizacija posebnog interesa za inovacioni sistem prema teritorijalnoj nadležnosti za donošenje zakona u ovoj oblasti.
1.4 Donesen Okvirni zakon o visokom obrazovanju u BiH (50/07 i 59/09)
2.4. Po iznosima i strukturi apsolutno nedovoljno i neadekvatno budžetsko finansiranje funkcionisanja inovacionog sistema, praćeno izostankom poticaja i povlastica za istraživanje i razvoj.
1.5. Uspostavljena međuzavisnost naučnog $\mathrm{i}$ nastavnog rada na univerzitetima

1.6. U toku je završetak stvaranja usaglašenog sistema strateškog

planiranja u BiH

\begin{tabular}{cc}
\hline 3. & \multicolumn{1}{c}{ Prilike } \\
\hline 3.1. & $\begin{array}{l}\text { Završetak zakonskog uređivanja sistema nauke } \\
\text { donošenjem novih zakona u šest kantona koji } \\
\text { to nisu učinili nakon potpisivanja Dejtonskog } \\
\text { mirovnog sporazuma. }\end{array}$
\end{tabular}

3.2. Donošenje 11 nedostajućih strategija razvoja inovacionog sistema (devet kantona, FBiH, Distrikt Brčko)

3.3. Razvijanje mehanizama povezivanja Ministarstva civilnih poslova BiH i subjekata inovacionog sistema u stvaranju i ispunjavanju oblika međunarodne saradnje.

2.5. /

2.6. $/$

4.

4.1. Legalna mogućnost nižih političko-teritorijalnih jedinica da ne koriste svoje nadležnosti i time umanje efekte nastojanja države u međunarodnoj naučnoj i tehničkoj saradnji

4.2. Autarhična primjena principa decentralizovanog i policentričnog planiranja razvoja inovacionog sistema

4.3. Ustavno-pravne i političke teškoće u djelovanju FBIH na harmonizaciji pravne i strategijske regulative inovacionog sistema 
3.4. Pojačavanje međunarodne razmjene $\mathrm{i}$ cirkulacije naučnoistraživačkih kadrova
4.4. Produbliivanje unutrašnjeg jaza u znanju iz objektivnih razloga (različit stepen razvijenosti kanona, npr.), političkih stavova i kulturološke situacije (stav prema društvu i ekonomiji znanja, npr.).

\section{Razrada elemenata faktora snage sažete SWOT matrice: Ujednačena struktura inovacionog sistema}

\begin{tabular}{cc}
\hline R.br. & \\
\hline \multicolumn{1}{|c}{ Snage } \\
\hline $\mathbf{1}$ & $\mathbf{2}$ \\
\hline 1.1. & $\begin{array}{l}\text { Ujednačena sistematizacija poslova u inovacio- } \\
\text { nom sistemu. Institutska i univerzitetska zvanja } \\
\text { su izjednačena, a uslovi za izbor veoma slični }\end{array}$ \\
\hline
\end{tabular}

1.2. Visokoškolsko obrazovanje je dio EHEA i funkcioniše na ujednačen način
R.br.

Slabosti

\section{3}

4

3.1. Nedovoljno učešće naučnika i istraživača u ukupnoj populaciji i u radnoj snazi

3.2. Postoje male razlike u uslovima za izbor nastavnika, istraživača i naučnih i saradnika, ali one imaju značajan efekt na mobilnost radne snage unutar inovacionog sistema u državi

3.3. I I ugla optimalnog funkcionisanja inovacionog sistema, svaka od sedam vrsta subjekata ima svoje specifične statusno-pravne slabosti

3.4. Nedovoljna produktivnost naučnog osoblja

3.5. Inovacioni sistem nije prioritet politike u zakonodavnom, planskom, strategijskom i finansijskom pogledu

3.6. Apsolutno nedovoljna izdvajanja za nauku i sasvim neadekvatan sistem finansiranja

1.7. /

1.8. /
3.7. Ne postoji sistemski pristup naučnoj etici kao kontrolnom mehanizmu društvenog karaktera i uslovu za odobrenje pojedinih projekata

3.8. Nezainteresiranost državne uprave za funkcionisanje i za učešće u radu inovacionog sistema.

4.

\section{Prijetnje}

4.1. Legalna mogućnost nižih političko-teritorijalnih jedinica da na svom području ne unapređuju i ne harmoniziraju legislativu inovacionog sistema

4.2. Suprotnost između postojanja državne nadležnosti za međunarodne odnose inovacionog sistema i nepostojanja ovlaštenja i instrumenata za implementaciju međunarodnih aranžmana unutar države 


\begin{tabular}{llll}
\hline 2.3. & $\begin{array}{l}\text { Povećanje iznosa i poboljšanje metodologije i } \\
\text { budžetskog finansiranja, poboljšanje strukture } \\
\text { finansiranja po subjektima i izvorima }\end{array}$ & 4.3. & $\begin{array}{l}\text { FBiH ima nadležnost za zakonsko uređivanje } \\
\text { ekonomskih i privrednih odnosa, ali ne i za } \\
\text { uređenje inovacionog sistema }\end{array}$ \\
\hline 2.4. & $\begin{array}{l}\text { Usklađivanje politike direktnih stranih ulaganja } \\
\text { sa strategijom i politikom inovacionog sistema }\end{array}$ & 4.4. & $\begin{array}{l}\text { Nepostojanje velikih privrednih organizacija koje } \\
\text { bi bile nosioci razvoja inovacionog sistema u } \\
\text { ekonomiji, ali i u državi }\end{array}$ \\
\hline
\end{tabular}

\begin{tabular}{|c|c|c|c|}
\hline \multicolumn{4}{|c|}{$\begin{array}{c}\text { Razrada elemenata faktora snage sažete SWOT matrice: } \\
\text { Dobro stanje ljudskog kapitala }\end{array}$} \\
\hline R.br. & & R.br & \\
\hline 1 & 2 & 3 & 4 \\
\hline 1. & Snage & 2. & Slabosti \\
\hline 1.1. & Dobar zdravstveni sistem & 2.1 & $\begin{array}{l}\text { Nedovoljno ulaganje, države prvenstveno, u sve } \\
\text { komponente ljudskog kapitala, a posebno u javno } \\
\text { zdravstvo }\end{array}$ \\
\hline 1.2. & $\begin{array}{l}\text { Obrazovni sistem usklađen sa evropskim } \\
\text { standardima }\end{array}$ & 2.2 & $\begin{array}{l}\text { Postojanje unutrašnjeg jaza u znanju. Ljudski } \\
\text { kapital u svim dijelovima države nije podjednako } \\
\text { razvijen niti ima iste razvojne uslove. }\end{array}$ \\
\hline 1.3. & $\begin{array}{l}\text { Još uvijek dobro stanje ljudskog kapitala koje } \\
\text { se manifestuje objektivnom sposobnošću } \\
\text { bosanskohercegovačke privrede da na } \\
\text { međunarodno tržište plasira složene izvozne } \\
\text { proizvode }\end{array}$ & 2.3 & $\begin{array}{l}\text { Nedovoljna koncentracija sopstvenog ljudskog } \\
\text { kapitala u samostalnim institutima i privrednim } \\
\text { subjektima }\end{array}$ \\
\hline 1.4 & $\begin{array}{l}\text { U inovacionom sistemu dominiraju istraživači } \\
\text { sa titulom doktora nauka }\end{array}$ & 2.4 & $\begin{array}{l}\text { Nepovoljan odnos između broja istraživača i drugih } \\
\text { zaposlenih u istraživačkim organizacijama }\end{array}$ \\
\hline 3. & Prilike & 4. & Prijetnje \\
\hline 3.1. & $\begin{array}{l}\text { Povećanje obuhvatnosti dobnih i stručnih } \\
\text { grupa zaposlenih odgovarajućim vidom } \\
\text { cjeloživotnog obrazovanja }\end{array}$ & 4.1. & $\begin{array}{l}\text { Dalja devalvacija znanja, vještina i kompetencija } \\
\text { u društvenom sistemu, u pod-sistemu politike } \\
\text { posebno. }\end{array}$ \\
\hline 3.2 & $\begin{array}{l}\text { Povećanje domaće potražnje za institutskim } \\
\text { znanjem i uslugama }\end{array}$ & 4.2 & $\begin{array}{l}\text { Nedovoljno brz rast informaciono-komunikacionih } \\
\text { vještina i kompjuterske pismenosti stanovništva. }\end{array}$ \\
\hline 3.3. & $\begin{array}{l}\text { STEM obrazovanje ponovo uključiti u državnu } \\
\text { obrazovnu politiku }\end{array}$ & 4.3. & Pad nataliteta, starenje stanovništva i emigracija \\
\hline 3.4 & $\begin{array}{l}\text { Jačanje dijelova sistema javnog zdravstva } \\
\text { relevantnog za održavanje i razvoj ljudskog } \\
\text { kapitala }\end{array}$ & 4.4. & Odliv pameti \\
\hline 2.5. & $\begin{array}{l}\text { Planskim akcijama uklanjati razlike između } \\
\text { deklaratornog i stvarnog odnosa prema } \\
\text { ljudskom kapitalu. }\end{array}$ & 4.5 & l \\
\hline
\end{tabular}




\begin{tabular}{|c|c|c|c|}
\hline \multicolumn{4}{|c|}{$\begin{array}{l}\text { Razrada elemenata faktora snage sažete SWOT matrice: } \\
\text { Ujednačeno i stabilizirano visoko obrazovanje }\end{array}$} \\
\hline R.br. & & R.br. & \\
\hline 1 & 2 & 3 & 4 \\
\hline 1. & Snage & 2. & Slabosti \\
\hline 1.1. & $\begin{array}{l}\text { Potpisane i primijenjene najvažnije konvencije } \\
\text { koje definišu EHEA }\end{array}$ & 2.1. & $\begin{array}{l}\text { Univerziteti su najvećim dijelom orijentisani } \\
\text { na održavanje nastave. Ne postoje istraživački } \\
\text { univerziteti. }\end{array}$ \\
\hline 1.2. & $\begin{array}{l}\text { Donesen i primijenjen Okvirni zakon o visokom } \\
\text { obrazovanju u BiH (Sl.gl. BiH 59/07 i 59/09). } \\
\text { Entitet RS i svi kantoni u Entitetu FBiH usvojili } \\
\text { svoje zakone u ovoj oblasti. }\end{array}$ & 2.2. & $\begin{array}{l}\text { Mali broj centara izvrsnosti i u političko- } \\
\text { teritorijalnim jedincima u kojima su zakonski } \\
\text { uređeni. }\end{array}$ \\
\hline 1.3. & Povoljna struktura univerziteta & 2.3. & Veoma ograničena saradnja sa privredom \\
\hline 1.4. & $\begin{array}{l}\text { Jedinstvo nauke i nastave postavljenu kao } \\
\text { princip i veliki dijelom ostvareno u praksi }\end{array}$ & 2.4. & $\begin{array}{l}\text { Nezadovoljavajući plasman svih domaćih } \\
\text { univerziteta na međunarodnim rang listama }\end{array}$ \\
\hline 1.5. & Izučavaju se sve naučne i umjetničke oblasti & 2.5 & Nedovoljni kapaciteti za transfer tehnologija \\
\hline 1.6. & Relativno dobar naučnonastavni kadar & 2.6. & $\begin{array}{l}\text { Ograničena sposobnost angažiranja najboljih } \\
\text { kadrova iz privrede i diplomiranih studenata }\end{array}$ \\
\hline 1.7. & $\begin{array}{l}\text { Postojanje instituta kao istraživačkih jedinica, } \\
\text { pretežno na javnim univerzitetima. }\end{array}$ & 2.7. & $\begin{array}{l}\text { Nedefinirana politika suprotstavljanja odlivu } \\
\text { pameti }\end{array}$ \\
\hline 3. & Prilike & 4. & Prijetnje \\
\hline 3.1. & $\begin{array}{l}\text { Ubrzano zapošljavanje stručnjaka deficitarnih } \\
\text { struka, naročito mlađih. }\end{array}$ & 4.1. & Spor razvoj autonomije visokoškolskih ustanova \\
\hline 3.2 . & $\begin{array}{l}\text { Utvrditi politiku i obezbijediti sredstva } \\
\text { za sistematičnu međunarodnu saradnju i } \\
\text { cirkulaciju kadrova }\end{array}$ & 4.2. & $\begin{array}{l}\text { Održavanje sadašnje strukture prihoda } \\
\text { visokoškolskih ustanova. Kod javnih to znači dalju } \\
\text { dominaciju budžeta, a kod privatnih - školarine. } \\
\text { Stagnacija prihoda od istraživanja i razvoja je } \\
\text { opasna i po univerztitete i po društvo }\end{array}$ \\
\hline 3.3. & $\begin{array}{l}\text { Donijeti strategiju i operativne dokumente za } \\
\text { formiranje centara izvrsnosti. }\end{array}$ & 4.3. & $\begin{array}{l}\text { Tendencije samoizolacije i provincijalizacije } \\
\text { univerziteta. }\end{array}$ \\
\hline 3.4. & $\begin{array}{l}\text { Planski pristup mjerama za povećanje } \\
\text { objavljivanja u časopisima koje prate indeksne } \\
\text { baze podataka i za popravljanje ranga naših } \\
\text { univerziteta, javnih naročito }\end{array}$ & 4.4. & $\begin{array}{l}\text { Zadržavanje sadašnjeg nivoa ulaganja u opremu i } \\
\text { načnoistraživačke projekte i istrajavanje na sistemu } \\
\text { nedovoljnog sufinansiranja nabavki i istraživanja }\end{array}$ \\
\hline 3.5. & $\begin{array}{l}\text { Donijeti opštu i strategije visokoškolskih } \\
\text { ustanova za saradnju sa privrednim subjektima }\end{array}$ & 4.5. & $\begin{array}{l}\text { Zadržavanje sadašnjeg nivoa ulaganja u opremu i } \\
\text { načnoistraživačke projekte i istrajavanje na sistemu } \\
\text { nedovoljnog sufinansiranja nabavki i istraživanja }\end{array}$ \\
\hline
\end{tabular}


Prilog 3.

Tabela br. 6: "Pregled objavljenih radova u Scopus bazi prema granama nauke i univerzitetima"

\begin{tabular}{|c|c|c|c|c|c|c|c|c|c|c|}
\hline \multirow[t]{2}{*}{ OBLAST } & \multicolumn{8}{|c|}{ UNIVERZITETI/SVEUČILIŠTA } & \multirow{2}{*}{$\frac{\text { SUMA }}{\Sigma}$} & \multirow{2}{*}{$\frac{\%}{\text { RADOVI }}$} \\
\hline & UNSA & UNBL & UNTZ & SVEM & UIS & UNZE & UNMO & UNBI & & \\
\hline Medicina & 2085 & 353 & 461 & 375 & 178 & 72 & 17 & 0 & 3541 & $19,9 \%$ \\
\hline Inžinjerstvo & 1264 & 494 & 341 & 116 & 202 & 101 & 63 & 0 & 2581 & $14,5 \%$ \\
\hline Kompjuterske nauke & 963 & 307 & 213 & 81 & 157 & 43 & 74 & 0 & 1838 & $10,3 \%$ \\
\hline $\begin{array}{l}\text { Poljoprivreda i biološke } \\
\text { nauke }\end{array}$ & 471 & 347 & 65 & 101 & 101 & 0 & 17 & 0 & 1102 & $6,2 \%$ \\
\hline Društvene nauke & 458 & 135 & 149 & 136 & 78 & 25 & 23 & 0 & 1004 & $5,6 \%$ \\
\hline Matematika & 461 & 200 & 70 & 37 & 82 & 27 & 10 & 0 & 887 & $5,0 \%$ \\
\hline Fizika i astronomija & 442 & 184 & 75 & 24 & 82 & 39 & 2 & 0 & 848 & $4,8 \%$ \\
\hline $\begin{array}{l}\text { Biohemija, genetika i } \\
\text { molekularna biologija }\end{array}$ & 360 & 166 & 66 & 85 & 52 & & 1 & 0 & 730 & $4,1 \%$ \\
\hline Nauka o zaštiti okoline & 273 & 147 & 90 & 38 & 58 & 11 & 7 & 0 & 624 & $3,5 \%$ \\
\hline Hemija & 188 & 120 & 58 & 41 & 96 & 17 & 2 & 0 & 522 & $2,9 \%$ \\
\hline Nauka o materijalima & 130 & 174 & 40 & 31 & 75 & 54 & 8 & 0 & 512 & $2,9 \%$ \\
\hline Hemijsko inžinjerstvo & 231 & 77 & 62 & 27 & 71 & 20 & 2 & 0 & 490 & $2,8 \%$ \\
\hline Energija & 194 & 96 & 84 & 10 & 79 & & 5 & 0 & 468 & $2,6 \%$ \\
\hline $\begin{array}{l}\text { Umjetnost i } \\
\text { humanističke nauke }\end{array}$ & 170 & 50 & 62 & 81 & 12 & 22 & 10 & 0 & 407 & $2,3 \%$ \\
\hline $\begin{array}{l}\text { Biznis, menadžment i } \\
\text { računovodstvo }\end{array}$ & 173 & 57 & 25 & 25 & 23 & 9 & 9 & 0 & 321 & $1,8 \%$ \\
\hline $\begin{array}{l}\text { Farmakologija, } \\
\text { toksikologija i } \\
\text { farmaceutika }\end{array}$ & 145 & 70 & 12 & 17 & 11 & 1 & 0 & 0 & 256 & $1,4 \%$ \\
\hline $\begin{array}{l}\text { Nauke o Zemlji i } \\
\text { planetama }\end{array}$ & 83 & 62 & 55 & 22 & 19 & 3 & 1 & 0 & 245 & $1,4 \%$ \\
\hline Zdravstvene studije & 88 & 25 & 42 & 41 & 43 & 2 & 3 & 0 & 244 & $1,4 \%$ \\
\hline $\begin{array}{l}\text { Donošenje odluka } \\
\text { (interdisciplinarno } \\
\text { područje) }\end{array}$ & 106 & 35 & 11 & 4 & 30 & 8 & 9 & 0 & 203 & $1,1 \%$ \\
\hline $\begin{array}{l}\text { Ekonomija, ekonometrija } \\
\text { i finansije }\end{array}$ & 111 & 35 & 17 & 12 & 18 & & 5 & 0 & 198 & $1,1 \%$ \\
\hline Fiziologija & 79 & 39 & 30 & 22 & 7 & 2 & 0 & 0 & 179 & $1,0 \%$ \\
\hline Veterina & 105 & 25 & 4 & 16 & 5 & 1 & 1 & 0 & 157 & $0,9 \%$ \\
\hline
\end{tabular}




\begin{tabular}{lcccccccccc}
\hline OBLAST & \multicolumn{1}{c}{ UNIVERZITETI/SVEUČILǏSTA } & & & SUMA & $\%$ \\
\hline $\begin{array}{l}\text { Imunologija i } \\
\text { Mikrobiologija }\end{array}$ & 79 & 12 & 11 & 18 & 7 & 0 & 0 & 0 & 127 & $0,7 \%$ \\
\hline Neuroznanost & 52 & 13 & 18 & 5 & 3 & 0 & 0 & 0 & 91 & $0,5 \%$ \\
\hline Sestrinstvo & 50 & 8 & 15 & 6 & 4 & 3 & 1 & 0 & 87 & $0,5 \%$ \\
\hline Stomatologija & 43 & 11 & & 9 & 20 & 1 & 0 & 0 & 84 & $0,5 \%$ \\
\hline $\begin{array}{l}\text { Mutidisciplinarna } \\
\text { područja }\end{array}$ & 36 & 15 & 6 & 4 & 7 & 0 & 2 & 0 & 70 & $0,4 \%$ \\
\hline & 8840 & 3257 & 2082 & 1384 & 1520 & 461 & 272 & 0 & $\mathbf{1 7 8 1 0}$ & \\
\hline$\%$ PO UNIVERZITETU & $49,6 \%$ & $18,3 \%$ & $11,7 \%$ & $7,8 \%$ & $8,5 \%$ & $2,6 \%$ & $1,5 \%$ & & & \\
\hline
\end{tabular}

\section{Zahvala}

Autori žele da se zahvale gospodinu Saši Madackom, diplomiranom komparativisti i diplomiranom bibliotekaru, na velikoj pomoći u obezbjeđivanju i sintezi podataka vezanih za broj visokoškolskih institucija u Bosni i Hercegovini i naučnoistraživačkih radova u SCOPUS bazi.

\section{Literatura}

Agencija za razvoj visokog obrazovanja i osiguranje kvaliteta Bosne i Hercegovine . Lista akreditiranih visokoškolskih ustanova u BiH. Preuzeto s http://hea.gov.ba/akreditacija vsu/Default.aspx, 10. 5. 2021.

Agencija za statistiku Bosne i Hercegovine. Demografija i socijalne statistike. Statistika obrazovanja - Visoko obrazovanje u školskoj 2019/2020. godini, Saopćenje (God. XV, Broj 2), Sarajevo, 30. 10. 2020.

Agencija za statistiku Bosne i Hercegovine. Nauka, tehnologija i digitalno društvo, Statistika Istraživanje i razvoj 2019, Saopćenje, God. IX (br. 1), Sarajevo, 12. 2. 2021.

Babić, M. (2021). Od Srbije čekamo da nam izbroji vakcinisane. Oslobođenje [Digital Edition]. 25. 5. 2021. Preuzeto s https://www.oslobodjenje.ba/vijesti/bih/od-srbije-cekamoda-nam-izbroji-vakcinisane-658782, 25. 5. 2021.

Bosna i Hercegovina. Centar za informiranje i priznavanje dokumenata iz oblasti visokog obrazovanja Bosne i Hercegovine. (2021). Lista visokoškolskih ustanova. Preuzeto s http://www.cip.gov.ba/images/pdf/ListaVSU/Lista_VSU.bos.pdf, 10. 5. 2021.

Bosna i Hercegovina. Okvirni zakon o osnovama naučno-istraživačke djelatnosti i koordinaciji unutrašnje i međunarodne naučno-istraživačke saradnje Bosne i Hercegovine Službeni glasnik Bosne i Hercegovine br. 43/09.

Bosna i Hercegovina. Okvirni zakon o visokom obrazovanju u Bosni i Hercegovini. Službeni glasnik Bosne i Hercegovine br. 59/07.

Bosna i Hercegovina. Ustav Bosne i Hercegovine. [Aneks IV Opšteg okvirnog sporazuma za mir u Bosni i Hercegovini]. Preuzeto s https://www.ustavnisud.ba/public/down/USTAV BOSNE_I_HERCEGOVINE_bos.pdf 
Bosna i Hercegovina. Vijeće Ministara Bosne i Hercegovine (2016). Strategija razvoja znanosti u Bosni i Hercegovini 2017-2022: revidirani okvirni dokument. Preuzeto s http:// www.vijeceministara.gov.ba/akti/prijedlozi_zakona/?id=29796, 20. 6. 2016.

Bosna i Hercegovina. Vijeće Ministara Bosne i Hercegovine (2020). Srednjoročni program rada Vijeća ministara BiH 2021-2023. Vijeće ministara Bosne i Hercegovine. Sarajevo. Preuzeto s https://www.ekonsultacije.gov.ba/legislationactivities/downloaddocument?do cumentId=1013796, 11. 6. 2021.

Bosna i Hercegovina. Vijeće Ministara Bosne i Hercegovine. (2014). Odluka Vijeća ministara $\mathrm{BiH}$ o postupku srednjoročnog planiranja, praćenja i izvještavanja u institucijama Bosne i Hercegovine. Službeni glasnik Bosne i Hercegovine br. 62/14.

Bosna i Hercegovina. Vijeće Ministara Bosne i Hercegovine. Direkcija za ekonomsko planiranje. (2015a). Strateški okvir za BiH. Direkcija za ekonomsko planiranje. Sarajevo. Preuzeto s http://www.dep.gov.ba/naslovna/DEP\%20Strateski\%20okvir\%20za\%20BiH. pdf, 2. 4. 2021.

Bosna i Hercegovina. Vijeće Ministara Bosne i Hercegovine. Direkcija za ekonomsko planiranje. (2015b). Strategija razvoja Bosne i Hercegovine. Direkcija za ekonomsko planiranje. Sarajevo. Preuzeto s http://www.dep.gov.ba/razvojni_dokumenti/razvojna strategija/Archive.aspx?langTag=bs-BA\&template_id=140\&pageIndex=1, 11. 6. 2021.

Bosna i Hercegovina. Vijeće Ministara. (2010). Strategija razvoja Bosne i Hercegovine, Radni dokument. Preuzeto s http://dep.gov.ba, 11. 6. 2021.

Bosna i Hercegovina. Vijeće Ministara. (2016). Odluka Vijeća ministara o sistemu koordinacije procesa europskih integracija u Bosni i Hercegovini Službeni glasnik Bosne i Hercegovine br. 72/16 Preuzeto s http://vijeceministara.gov.ba/home_right_docs/default. aspx?id=23422\&langTag=hr-HR, 11. 6. 2021.

Bosna i Herceogovina. Vijeće Ministara. (2015). Strateški okvir za Bosnu i Hercegovinu. Preuzeto s http://dep.gov.ba/naslovna/DEP\%2'strateski\%20okvir\%20za\%20BiH.pdf, 11. 6. 2021.

Božac, M.G. (2008). SWOT analiza i TOWS matrica - sličnosti i razlike. Ekonomska istraživanja. Vol. 21 (br. 1), str. 20-23.

Consejo Superior de Investigaciones Científicas (2021). Ranking Web of Universities Bosnia and Herzegovina. Preuzeto s https://webometrics.info/en/Europe/Bosnia\%20 and\%20Herzegovina\%20, 11. 6. 2021.

Cvitković, I. [ur.] (2017). Demografske i etničke promjene u BiH, Akademija nauka i umjetnosti Bosne i Hercegovine, Sarajevo.

Čičić, M. [ur.] (2020). Studija o emigracijama Bosne i Hercegovine. Akademija nauka i umjetnosti Bosne i Hercegovine, Sarajevo.

Emirhafizović, M. i Zolić, H. (2017). Dobna struktura i reprodukcija stanovništva Bosne i Hercegovine. [ur.] Cvitković, I. Demografske i etničke promjene u BiH, ( str. 11-54). Akademija nauka i umjetnosti Bosne i Hercegovine, Sarajevo.

European Comission. (2019). The European Charter for Researchers: The Code of Conduct for the Recruitment. Office for Official Publications of the European Communities. Luxembourg. Preuzeto s https:/www.unsa.ba/sites/default/files/inline-iles/EU\%20Povelja\%20i\%20Kodeks\%20za\%20istrazivace_BOS.pdf, 11. 6. 2021.

Evropska. Komisija. (2021). EURAXESS - Researchers in Motion. Preuzeto s https://euraxess.ec.europa.eu/, 11. 6. 2021.

Federacija Bosne i Hercegovine. Bosansko-podrinjski kanton Goražde. (2015) Strategija razvoja Bosansko-podrinjskog kantona Goražde za period 2016-2020. godine, Preuzeto 
s Http:// www. zzpr.gov.ba/bs/docs/25/4/kantonalni zzh.ba/images/PDF/Strategije/Strategija\%20razvoja\%20Zupanije\%20Zapadnohercegovacke\%202021-2027-RADNA\%20 VERZIJA.pdf -strateski-dokumenti, 11. 6. 2021.

Federacija Bosne i Hercegovine. Federalni zavod za programiranje razvoja. Uredbe. Preuzeto s https://www.fzzpr.gov.ba/bs/docs/35/8/uredbe

Federacija Bosne i Hercegovine. Federalni zavod za programiranje razvoja. Kantonalnoi strateški dokumenti. Preuzeto s https://fzzpr.gov.ba/public/bh/strateski-dokumenti/kantonalni-strateski-dokumenti, 11. 6. 2021.

Federacija Bosne i Hercegovine. Federalno ministartsvo obrazovanja i nauke (2010). Strategija razvoja nauke u Federaciji Bosne i Hercegovine za period 2011 - 2021. Federalno ministarstvo obrazovanja i nauke. Mostar.

Federacija Bosne i Hercegovine. Hercegovačko-neretvanska županija. 2020).. Strategija razvitka Hercegovačko-neretvanske županije za period 2021. - 2027. - Nacrt strateške platforme. Preuzeto s https://www.vlada-hnz-k.ba/sites/default/files/17.11.strateska_platfroma_hnk_2021_2027_nacrt_mm_1.pdf, 11.6.2021.

Federacija Bosne i Hercegovine. Kanton 10. (2015). Strategija razvoja kantona 10 za period 2016 - 2020: Nacrt. Preuzeto s https:/www.fzzpr.gov.ba/bs/docs/25/4/kantonalni-strateski-dokumenti, 11. 6. 2021.

Federacija Bosne i Hercegovine. Kanton Sarajevo. (2020). Strategija razvoja Kantona Sarajevo, Nacrt - proširena verzija. Preuzeto s https://zpr.ks.gov.ba/strategija-razvoja-kantona-sarajevo-2021-2027strateska-platforma-nacrt-prosirena-verzija, 11. 6. 2021.

Federacija Bosne i Hercegovine. Srednjobosanki kanton. (2016). Preuzeto s https://sbk-ksb. gov.ba/images/Strategija_razvoja_SBK_2016-2020.pdf, 11.6. 2021.

Federacija Bosne i Hercegovine. Tuzlanski Kanton. (2015). Nacrt strateške platforme razvoja Tuzlanskog kantona. Preuzeto s http://www.vladatk.kim.ba/Vlada/Novosti_2014/ Nacrt_Strateske_platforme_razvoja_Tuzlanskog_kantona.pdf, 11. 6. 2021.

Federacija Bosne i Hercegovine. Unsko-sanski kanton. (2014). Integrirana strategija razvoja Unsko-sanskog kantona, Preuzeto s https://www.fzzpr.gov.ba/bs/docs/25/4/kantonalnistrateski-dokumenti, 11. 6. 2021.

Federacija Bosne i Hercegovine. Uredba o izradi strateških dokumenata u Federaciji Bosne i Hercegovine. Službene novine Federacije Bosne i Hercegovine br. 74/19

Federacija Bosne i Hercegovine. Vlada Federacija Bosne i Hercegovine. (2020). Strategija razvoja Federacije Bosne i Hercegovine. Preuzeto s http://fzzpr.dgov.ba/bs/pages/48/16/ strategija-razvoja-federacije-bih-2021-2027, 11. 6. 2021.

Federacija Bosne i Hercegovine. Vlada Federacije Bosne i Hercegovine (2021). Strategija razvoja Federacije Bosne i Hercegovine 2021-2027. Vlada Federacije Bosne i Hercegovine. >Sarajevo. Preduzeto s http://www.sogfbih.ba/sites/default/files/javni_dokument/2021-05/Strategija\%20razvoja\%20FBiH\%202021.\%20-\%202027..pdf, 11. 6 . 2021.

Federacija Bosne i Hercegovine. Zakon o razvojnom planiranju i upravljanju razvojem u Federaciji Bosne i Hercegovine. Službene novine Federacije Bosne i Hercegovine br. $32 / 17$.

Federacija Bosne i Hercegovine. Zeničko-dobojski kanton. (2020). Strategija razvoja Zeničko-dobojskog kantona za period 2021 - 2027: Nacrt. Preuzeto s https://www.zdk. ba/component/k2/item/download/5098_caae7a6c7e858099211e354ca553e6ec, 11. 6 . 2021. 
Federacija Bosne i Hercegovine. Županija Posavska. (2021). Strategija razvija Županije Posavske 2021-2027. Županija posavska. Preuzeto s http://www.zupanijaposavska. ba/wp-content/uploads/2020/11/FINALNI-NACRT-V2-Strategija-razvoja-ZupanijePosavske-10-11-2020-2 compressed.pdf, 11. 6. 2021.

Federacija Bosne i Hercegovine. Županija Zapadnohercegovačka (2021). Strategija razvoja Županije Zapadnohercegovačke 2021 - 2027. Preuzeto s http:/www.eui-zzh.ba/images/ PDF/Strategije/Strategija_razvoja_ZZH_za_razdoblje_2021_-_2027_godine.pdf , 11. 6 . 2021.

Federalni zavod za statistiku. (2020). Projekcije stanovništva Federacije Bosne i Hercegovine 2020 - 2070. Federalni zavod za statistiku. Sarajevo. Preuzeto s https://fzs.ba/wpcontent/uploads/2020/12/PROJEKCIJE-STANOVNI\%C5\%A0TVA-FBiH-2020_2070_ bos.pdf, 11. 6. 2021.

Federalni zavod za statistiku. (2020). Statistički bilten Visoko obrazovanje 2019/2020, broj 306, Sarajevo.

Federalni zavod za statistiku. Visoko obrazovanje u Federaciji Bosne i Hercegovine u 2020./2021. Saopćenje (God. XIII, Broj 12.3), Sarajevo, 3. 3. 2020.

Fleisher, C. i Bensoussan, B. (2007). Business and Competitive Analysis: Effective Application of New and Classic Methods. Pearson Education. Upper Saddle River, New Jersey.

https://www.weforum.org/reports/the-global-competitiveness-report-2017-2018, 24.3. 2021.

Kanton Sarajevo. Vlada kantona Sarajevo. Ministarstvo za obrazovanje, nauku i mlade Kantona Sarajevo (2017). Strategija razvoja obrazovanja i nauke Kantona Sarajevo za period 2018 - 2022. godine - (Nacrt). Ministarstvo za obrazovanje, nauku i mlade Kantona Sarajevo. Sarajevo. Preuzeto s https://skupstina.ks.gov.ba/sites/skupstina.ks.gov.ba/files/ nacrt_strategije_obrazovanje.pdf, 11.6.2021.

Kanton Sarajevo. Vlada kantona Sarajevo. Ministarstvo za obrazovanje, nauku i mlade Kantona Sarajevo Standardi i normativi za obavljanje djelatnosti visokog obrazovanja na području Kantona Sarajevo. Službene novine Kantona Sarajevo br. 33/17

Kremić, E. I Trifković, M. [ur.] (2020). Harmonizacija sistema nauke u Bosni i Hercegovini: projekt $=$ Harmonization of the science system in Bosnia and Herzegovina : project. Federalni zavod za statistiku = Institute for Statistics of the Federation of Bosnia and Herzegovina : Akademija nauka i umjetnosti Bosne i Hercegovine = Academy of Sciences and Arts of Bosnia and Herzegovina. Sarajevo.

Nikolić, R. (s.a.). SWOT analiza: šta je to i kako se primenjuje. [Digital Edition]. Preuzeto sa www.issu.com/bisera.kardula/docs/1913_m_chapter_3_swor_manual_r-niko, 27. 3 . 2021.

Pašalić-Kreso, A. (2017). Obrazovanost stanovništva u Bosni i Hercegovini - Bosna i Hercegovina između najviše stope nepismenosti i najnižeg nivoa obrazovanosti“ [ur.] Cvitković, I. Demografske i etničke promjene u BiH, (str. 93-124). Akademija nauka i umjetnosti Bosne i Hercegovine, Sarajevo.

Radošević, S. (2011). Science-industry links in Central and Eastern Europe and the Commonwelth of Independent States: conventioanla policy wisdom faciong reality. Science and Public Policy. Vol 38 (br. 5), str. 365-378.

Radošević, S., i Lepori, B. (2009). Public Research Funding Systems in Central and Eastern Europe: Between Excellence and Relevance: Introduction to Special Section. Science and Public Policy, Vol. 36 (br. 9), str. 659-666. 
Repbublika Srpska. Narodna skuppština Republike Srpske. Materijali za 16. Redovnu sjednicu. Preuzeto sa: http:/www.narodnaskupstinars.net/sites/default/files/upload/dokumenti/materijali_za_sjednice/lat/Materijali\%20za\%2016.\%20redovnu\%20sjednicu.zip, 26. 4. 2021.

Republički zavod za statistiku Republike Srpske. (2020) .Statistički bilten 2019/2020, Banja Luka,

Republika Srpska. Ministartsvo za naučnotehnološki razvoj, visoko obrazovanje i informaciono društvo. Strategije. Preuzeto sa https://www.vladars.net/sr-SP-Cyrl/Vlada/Ministarstva/mnk/PAO/Strategije/Pages/default.aspx, 11. 6. 2021.

Republika Srpska. Vlada Republike Srpske (2017). Strategija naučnog i tehnološkog razvoja Republike Srpske 2017 - 2021. godine - Znanje za razvoj. Vlada Republike Srpske. Banja Luka. Preuzeto s https://www.vladars.net/sr-SP-Cyrl/Vlada/Ministarstva/mnk/Documents/PRIJEDLOG\%20-\%20\%20strategije\%20naucnog\%20i\%20tehnoloskog\%20razvoja\%20RS\%202017-2021\%20\%286\%29.pdf, 11. 6. 2021.

Republika Srpska. Zakon o naučnoistraživačkoj djelatnosti i tehnološkom razvoju. Službeni glasnik Republike Srpske br. 6/12, 33/14 66/18 i 84/19. Preuzeto s http://spu.ba/wpcontent/uploads/2018/02/zakon_o_naucnoistrazivackoj_djelatnosti_i_tehnoloskom_razvoju.pdf, 11. 6. 2021.

Republika Srpska. Zakon o visokom obrazovanju. Službeni glasnik Republike Srpske br. $67 / 202$

Schwab, K. (2017). The Global Competitiveness Report 2017-2018. [Digital Edition]. World Economic Forum. Cologny/Geneva. Preuzeto sa

Schwab, K. (2019). The Global Competitiveness Report 2019. [Digital Edition]. World Economic Forum. Cologny/Geneva. Preuzeto shttp://www3.weforum.org/docs/WEF_TheGlobalCompetitivenessReport2019.pdf, 24. 3. 2021.

Statista (2021). Number of novel coronavirus (COVID-19) deaths worldwide as of May 24, 2021, by country. Preuzeto s https://www.statista.com/statistics/1093256/novel-coronavirus-2019ncov-deaths-worldwide-by-country/, 24. 5. 2021.

Steiner, C. [et. al.] (2010). Ustav Bosne i Hercegovine : komentar. Fondacija Konrad Adenauer e.V. Sarajevo.

Trifković, M. (2020a). Uticaj Dejtonskog mirovnog sporazuma na inovacioni sistem u Bosni i Hercegovini. Dijalog, 2020 (br. 3-4), str. 40-59. ISSN 0350-6177.

Trifković, M. (2020b). Harmonizacija sistema nauke u Bosni i Hercegovini. Akademija nauka i umjetnosti Bosne i Hercegovine. Sarajevo.

Trifković, M. [ur.] (2020c). Zadržavanje mladih u Kantonu Sarajevo: analiza determinanti i prijedlog strateških mjera“. Akademija nauka i umjetnosti Bosne i Hercegovine, Sarajevo.

Wikipedia (2021). List of countries by GDP (PPP) per capita. Preuzeto s https://en.wikipedia. org/wiki/List_of_countries_by_GDP_(PPP)_per_capita, 24. 3. 2021.

World Bank (2021). World bank Data: Science and Technology. Preuzeto s https://data. worldbank.org/topic/14, 26. 3. 2021.

World Intelectual Property Organization (2020). Global Innovation Index. Bosnia and Herzegovina. Preuzeto s https://www.wipo.int/edocs/pubdocs/en/wipo_pub_gii_2020/ba.pdf, 24. 3. 2021. 